\title{
Casa, familia, heredad. La colección fotográfica de caseríos vascos de Fr. Pedro de Madrid, $1912^{1}$
}

\author{
House, Family, Estate. The Photographic Collection \\ of Basque Farmhouses of Fr. Pedro de Madrid, 1912
}

\author{
José Javier Azanza López \\ Departamento de Historia, Historia del Arte y Geografía. \\ Universidad de Navarra \\ Roberto San Martín Casi \\ Biblioteca de Navarra
}

\section{RESUMEN}

Este trabajo pretende dar a conocer la colección fotográfica de caseríos vascos del valle de Baztán (Navarra) que bajo el lema Echezarra (Casa vieja) resultó premiada en el Certamen fotográfico-social celebrado en 1912 en Pamplona, poniendo de relieve su carácter inédito y su notable valor artístico, documental e ideológico; no en vano, las imágenes conjugan en armonía caserío, familia y heredad, para componer un inmejorable testimonio de los modos de vida en Baztán de hace un siglo, participando plenamente de la visión arcádica de los valores encarnados por el campesino vasco, alejada de la realidad, pero tan arraigada en el pensamiento tradicional de la época. Y, a su vez, quiere resaltar la figura prácticamente desconocida de su autor, Fr. Pedro de Madrid (Pedro Satué), religioso capuchino que se inició en las técnicas del arte fotográfico en el Colegio de Lekaroz para, una vez secularizado, acabar desarrollando la profesión en el estudio que abrió en Madrid, especializándose en el retrato artístico.

Palabras clave: Certamen fotográfico-social, Siglo XX, Valle de Baztán, Navarra, Fr. Pedro de Madrid, Caserío vasco.

\section{SUMMARY}

This paper seeks to highlight the photographic collection of Basque farmhouses of Baztan Valley (Navarra) that, under the motto Echezarra (Old House), was awarded in the PhotographicSocial Competition held in 1912 in Pamplona, emphasizing its unpublished nature and its remarkable artistic, documentary and ideological value; not in vain, the images combine in harmony farmhouse, family and estate, to create a superb testimony of lifestyles in Baztan Valley of a Century ago, participating fully in the arcadic vision of the values embodied by the Basque farmer, far

\footnotetext{
${ }^{1}$ Deseamos manifestar nuestro más sincero agradecimiento a las siguientes personas e instituciones que han contribuido a la elaboración de este trabajo: Archivo de Capuchinos de Pamplona; Archivo Municipal de Pamplona; Archivo Municipal Pilar Arostegui de Vitoria; Institución Príncipe de Viana; Museo San Telmo de Donostia-San Sebastián; José Luis Larrión, fotógrafo; P. Tarsicio de Azcona (O.F.M. Cap.); José Ángel Echeverría (O.F.M. Cap.); José Ma Oyaregui e Higinia Arriada de Elizondo; y Josemari Urtsuegui de Gartzain.
} 
from reality but deeply rooted in the traditional thinking of the time. And, at the same time, it wants to highlight the virtually unknown figure of its author, Fr. Pedro de Madrid (Pedro Satué), Capuchin Friar started in the photographic techniques in the Convent of Lekaroz for, secularized once, develop the profession in the Studio that he opened in Madrid, where he specialized in artistic portrait.

Key words: Photographic-Social Competition, $20^{\text {th }}$ Century, Baztan Valley, Navarre, Fr. Pedro de Madrid, Basque Farmhouse.

\section{PAMPLONA 1912: VII CENTENARIO DE LAS NAVAS, VI SEMANA SOCIAL Y CERTA- MEN FOTOGRÁFICO}

En el mes de julio de 1912, Pamplona y Navarra entera conmemoraron el VII Centenario de la batalla de las Navas de Tolosa, efeméride con motivo de la cual la Diputación Foral auspició, a instancias de la Comisión de Monumentos Históricos y Artísticos de Navarra, un programa de actos de muy variada naturaleza (Azanza López 2012), entre los que figuraba la celebración de la VI Semana Social, muestra evidente del auge que en Navarra había logrado el cooperativismo agrario católico, gracias a la intensa actividad de su Federación Católico-Social (Majuelo y Pascual 1991: 78-79).

Entendidas como una "Universidad ambulante", las Semanas Sociales ${ }^{2}$ eran encuentros periódicos de la "inteligencia" social católica española para exponer y analizar los principales males de la sociedad moderna, disgregadores de los valores católicos tradicionales, a la par que abordar los problemas concretos del asociacionismo católico (Majuelo y Pascual 1991: 69-142). Tras su inauguración el 29 de junio con misa en la Catedral de Pamplona oficiada por el obispo López Mendoza y alocución a cargo del conocido y controvertido sociólogo dominico P. Pedro Gerard, las actividades de la VI Semana Social continuaron a lo largo de los días siguientes, incluida una visita a Olite para conocer sus obras sociales, hasta el momento de su clausura el 6 de julio (Goñi Gaztambide 1999: 568-599). En suma, y pese a ciertas disensiones internas, la VI Semana Social supuso un nuevo paso del asociacionismo católico en Navarra y España (Majuelo y Pascual 1991: 89-90), cuyos resultados quedaron plasmados en el grueso volumen que vio la luz en Pamplona en $1916^{3}$.

Dentro de las acciones programadas en el marco de la VI Semana Social tuvo lugar un certamen fotográfico-social, cuya primera noticia data del 14 de enero de 1912, cuando la comisión organizadora adoptó entre otros acuerdos la convocatoria de una exposición fotográfica, encomendando su organización al promotor de la iniciativa, el abogado y publicista José de Posse y Villelga, activo propagandista católico y ponente en la Semana con una serie de lecciones tituladas La vida social en el País Vasco,

\footnotetext{
${ }^{2}$ En 1906, siguiendo el ejemplo de las de Francia, nacieron en España las Semanas Sociales, que en una primera etapa reunieron en seis convocatorias a lo más granado del catolicismo social. La primera se celebró en Madrid en 1906; la segunda en Valencia en 1907; la tercera en Sevilla en 1908; la cuarta en Santiago en 1909; la quinta en Barcelona en 1910; y la sexta en Pamplona en 1912. Posteriormente se interrumpieron hasta la Segunda República, celebrándose de forma irregular a lo largo del siglo XX hasta nuestros días.

3 Semana Social de España. Sexto curso... Pamplona: La Acción Social, 1916.
} 
muy en consonancia con el espíritu del certamen ${ }^{4}$. En realidad, tras esta iniciativa se encontraba la Academia Literaria del Patronato Obrero de Bilbao, asociación fundada en 1887 con el apoyo de la familia de empresarios Ybarra que supuso el origen de toda la acción social católica de Vizcaya (Olabarri Gortazar 1978: 120-122; Díaz Morlán 2002: 230-232).

El programa definitivo del certamen venía firmado en Bilbao el 15 de abril de 1912 por José de Posse y Félix Omaña, presidente y secretario de la comisión organizadora del concurso respectivamente, y Joaquín Nebreda, presidente de la Academia Literaria del Patronato Obrero 5 . Seis eran los temas objeto de representación: el I correspondía a la colección de fotografías que representasen "escenas del trabajo en el mar"; el II, "escenas del trabajo en el campo"; el III, "escenas del trabajo en fábricas y talleres"; el IV, "escenas del trabajo en las minas"; el V, "fotografías de caseríos vascos"; y el VI, "tipos de obreros vascos". Se establecían además dos temas especiales, dedicados respectivamente a las mejores colecciones de fotografías de los "edificios, fiestas e instituciones sociales de la Asociación Católica", y de las "colonias industriales o agrícolas establecidas en España". En todas las categorías se otorgarían premios en metálico y objetos de arte, obsequio de ilustres personalidades políticas y eclesiásticas; también se sumaron a la iniciativa con su apoyo económico las Diputaciones de Guipúzcoa, Álava y Navarra, y el Ayuntamiento de Pamplona.

Las condiciones del certamen especificaban que éste era libre para fotógrafos profesionales y aficionados, si bien todas las fotografías habían de referirse obligatoriamente al ámbito vasco-navarro, excepción hecha del tema II especial (colonias industriales o agrícolas establecidas en España). Llevarían un lema, y debían entregarse personalmente o enviarse certificadas por correo a la comisión organizadora en Bilbao; el plazo de admisión finalizaba el 15 de junio de 1912. Las instantáneas premiadas quedarían en propiedad de la entidad organizadora — el Patronato Obrero de Bilbao-, pasando a formar parte de la exposición permanente del Museo Social Vasco, cuya apertura en la capital vizcaína estaba prevista para el siguiente otoño; sin embargo, este centro no llegaría a inaugurarse, por lo que las colecciones tampoco engrosaron sus fondos ${ }^{6}$. Previamente, con las fotografías presentadas se organizaría una

\footnotetext{
${ }^{4}$ Aunque nacido en Segovia en 1881, José de Posse y Villelga desarrolló su labor profesional en Bilbao, donde desempeñó diferentes cargos en la primera mitad del siglo XX, fomentando innumerables iniciativas encaminadas al desarrollo de la política social y económica vizcaína; fueron muy conocidos sus escritos y conferencias sobre este tema, incluido un "catecismo social" (Fusi Aizpurúa 1975; Olábarri Gortazar 1978; Delgado Cendagortagalarza 2008 y 2009). Su afán publicista le llevó a editar, antes de que se publicaran las actas de la VI Semana Social, sus conferencias en la misma bajo el título La vida social en el País Vasco. Lecciones pronunciadas en la VI Semana Social de Pamplona. Durango: Imp. y Lib. F. Elosu, 1914.

${ }^{5}$ Archivo Municipal de Pamplona (AMP). Diversiones públicas. Ferias y fiestas, 1911-1912. Año 1912.

${ }^{6}$ Los Museos Sociales son instituciones de "beneficencia cultural obrera" que surgen en Europa (París, Berlín, Viena) impulsados por políticos, empresarios y patronos bajo la doctrina social de la Iglesia, con el objeto de mejorar a través de la formación las condiciones de vida de las clases trabajadoras. En 1909 se crea en Barcelona, a iniciativa de la Diputación y el Ayuntamiento, el primer y único Museo Social que existirá en España (Benavent Oltra 2008: 81). Ese mismo año, animado por el ejemplo catalán, el Patronato Obrero de Bilbao proyecta la creación de un Museo Social Vasco en Bilbao, iniciativa de la que se hicieron eco tanto la prensa local como algunas publicaciones católicas. Sin embargo, pese a estar prevista su inauguración para el otoño de 1912, ésta no llegó a
} 
exposición en Pamplona con motivo de la Semana Social, los Sanfermines y el Centenario de las Navas, y en agosto ésta se trasladaría a Bilbao, coincidiendo con sus fiestas patronales.

La exposición fotográfica quedó instalada a comienzos de julio en las Escuelas Municipales de San Francisco de la capital navarra, y reunió más de 600 fotografías, presentándose un total de 25 colecciones a los temas del concurso, todas ellas en sintonía con el espíritu del catolicismo social que durante aquellos días impregnaba la ciudad. La imagen de conjunto que transmitían era sintetizada así en El Eco de Navarra:

Figuran en la exposición grupos tan notables de fotografías del país, escenas fabriles y campestres tan exactamente reproducidas, tipos tan definidos y vistosos, paisajes de tan exacta fidelidad que no es necesario, para sentirlos, sino haber convivido unos meses con nuestros labriegos, haber visitado nuestros más importantes centros de explotación fabril y haber hecho una sola ascensión del valle a la montaña, respirando el ambiente aromatizado por la más espontánea y exuberante de las vegetaciones. Es la vida toda del país vasco, trasplantada a los reducidos límites de una galería expositiva ${ }^{7}$.

Integraron el Jurado tres fotógrafos, el profesional José Roldán Bidaburu y los aficionados Julio Altadill y Antonio García de la Peña. En su fallo repartían los premios correspondientes a todas las categorías con excepción de las "escenas del trabajo en fábricas y talleres" y "escenas del trabajo en las minas", que quedaron desiertas al haberse presentado fuera de concurso sus instalaciones fotográficas. Y aunque por desgracia no tenemos noticia de la ceremonia de entrega de premios, en la que sin duda se desveló la identidad de los galardonados, podemos relacionar algunos lemas y autores merced a las reseñas de prensa posteriores a la celebración del concurso. Es el caso de Enrique Guinea, uno de los pioneros de la fotografía en Vitoria ${ }^{8}$, quien bajo el lema Ego sum se alzó con el primer premio en la categoría de "escenas de trabajo en el campo", y premio especial en el tema de "Fotografías de Centros y Patronatos Católicos" ${ }^{9}$. Otro de los galardonados fue Jesús de Echebarria ${ }^{10}$, cuyo lema Airrabeche

materializarse, aunque la idea no se desestimó por completo: en 1920, en el II Congreso de Estudios Vascos celebrado en Pamplona, de nuevo José de Posse —el promotor del certamen fotográfico- insistirá en la necesidad de crear un Museo Social (Posse y Villelga 1920: 399); dos años más tarde, en el III Congreso celebrado en Guernica, el geógrafo y pedagogo navarro Leoncio Urabayen propondrá la creación de un Museo Social como el de Barcelona a fin de promover el desarrollo social y laboral del País Vasco.

7 "El certamen fotográfico", El Eco de Navarra, 24-7-1912: 1.

${ }^{8}$ Enrique Guinea Maquibar (Vitoria, 1875-1944) desarrolló una extensa labor como fotógrafo aficionado desde los primeros años del siglo XX, colaborando en periódicos y revistas ilustradas nacionales y obteniendo premios en certámenes nacionales e internacionales. Variada resulta la temática de su obra, en la que muestra especial predilección por los acontecimientos locales, retratos y escenas costumbristas con la presencia humana como constante. Vitoria-Gasteiz. Historia gráfica 1993; Enrique Guinea Maquibar, 1902-1944: fotografias 2010.

9 "Enrique Guinea", Heraldo Alavés, 10-7-1912: 1; "Festejando un triunfo", Heraldo Alavés, 227-1912: 1.

${ }^{10}$ Jesús de Echebarria e Ibargüengoitia (Bilbao, 1882-1962) fue un fotógrafo amateur entusiasta de la fotografía estereoscópica y muy aficionado a retratar paisajes humanizados, con notables trabajos que le valieron importantes premios en concursos nacionales (Bilbao, Santander, Tarragona, Soria, además de Pamplona). 
—su propio apellido leído del revés - mereció dos segundos premios en las categorías de "tipos de obreros vascos" y premio especial para aficionados; algunas de las fotografías pertenecientes a la colección de tipos vascos ilustraron en los meses siguientes las páginas de revistas como La Baskonia y Novedades ${ }^{11}$. Participó igualmente Manuel López Miranda, relacionado con los establecimientos fotográficos donostiarras y colaborador de Novedades (Elorza Insausti 2011), que obtuvo un segundo premio ${ }^{12}$. Y también el fotógrafo Llopis, colaborador de La Gaceta del Norte, quien con el lema La naturaleza y el arte se hizo acreedor a dos segundos premios en las categorías de "trabajo en el campo" y "caseríos vascos" "13.

Mas el verdadero triunfador fue el fraile capuchino Fr. Pedro de Madrid, profesor de dibujo y pintura y fotógrafo del Colegio de Lekaroz, que obtuvo los principales galardones con su colección fotográfica de caseríos del Valle de Baztán presentada bajo el lema Echezarra.

\section{FR. PEDRO DE MADRID (PEDRO SATUÉ): SEMBLANZA DE UN RELIGIOSO Y FO- TÓGRAFO DESCONOCIDO}

Fr. Pedro de Madrid, en el siglo Pedro Satué Blanco, nació el 31 de enero de 1880 en Madrid (Lasa 2006: 64), en el seno de una familia de clase media que se completaba con otros dos hermanos. Su padre, Pedro Satué, era funcionario en la Secretaría del Senado ${ }^{14}$, y su madre, Manuela Blanco, procedía de una familia burguesa abulense. En sus primeros años de vida creció en un ambiente cómodo, recibiendo una cuidada educación; pero la temprana muerte de su padre en 1893, a los 41 años de edad, provocará el deterioro de la situación económica familiar ${ }^{15}$. En 1894 Pedro Satué ingresa en la Escuela Seráfica de Lekaroz, Seminario-Colegio recién fundado (1888-1890) por el capuchino P. Joaquín M ${ }^{a}$ de Llevaneras, Provincial de los capuchinos de Castilla y máximo responsable de la Procura de Misiones conocida como Distrito Nullius Matritense (Zudaire Huarte 1989: 60-62) ${ }^{16}$.

\footnotetext{
${ }^{11}$ "Un aldeano, por Jesús de Echebarria", Novedades, n 167, 28-7-1912: 1; "Descansando", Novedades, $\mathrm{n}^{\mathrm{o}}$ 171, 29-9-1912: 1; la misma fotografía y título aparecen también en La Baskonia, $\mathrm{n}^{\mathrm{o}}$ 689, 20-11-1912: 1; "Tipos vascos: un aldeano", Novedades, no 184, 29-12-1912: 1.

${ }^{12}$ La información se insertaba como pie de foto de "Muturka", una de las fotografías premiadas de Manuel López Miranda. "Muturka", Novedades, 22-9-1912: 19.

13 "De la Exposición fotográfica", La Gaceta del Norte, 1-8-1912: 1. Debemos identificarlo con casi toda probabilidad con el fotógrafo de Bilbao Santiago Llopis (Fernández Rius 2011: 531).

${ }^{14}$ Expediente personal de Pedro Satué y Arreo, Escribiente $1^{\circ}$ de la Secretaría del Senado. Sign. HIS-0552-02. Archivo del Senado. Base de datos Morlesin, 1834-1931. Documentos. Sign. HIS-0702.

15 Viuda con 40 años, Manuela Blanco deberá sacar adelante a sus tres hijos con una corta pensión de viudedad que además, por cuestiones legales y burocráticas, se demorará bastantes años en cobrar; sólo a partir de 1898 percibirá mil pesetas anuales del Montepío de Ministerios. Acuerdos de la Comisión del Gobierno Interior. Archivo del Senado. Base de datos Morlesin. Signs. HIS-0702-01, carp. 9; HIS-0702-04, carp. 2, 6. Gaceta de Madrid, 18-1-1898: 185.

${ }^{16}$ Hasta su disolución en 1907, el Distrito Nullius Matritense estuvo integrado por los conventos madrileños de Jesús de Medinaceli y de El Pardo, y el Colegio de Lekaroz, circunstancia que favorecerá las estancias temporales por estudios y formación en la capital de algunos frailes residentes en el centro navarro.
} 
Aunque pueda sorprender que un muchacho madrileño arribe a un apartado convento del Valle de Baztán, debemos tener presente que existían en Madrid círculos sociales de señoras benefactoras que colaboraban activamente en los proyectos del P. Llevaneras (Zudaire Huarte 1989: 31-32). Probablemente su madre pertenecía a uno de esos grupos y, al enviudar, acordó con el fundador de Lekaroz enviarlo como estudiante seráfico al Colegio, un internado que compaginaba la formación de vocaciones religiosas con la de bachilleres y estudiantes de Comercio, y que en sus primeros años de andadura se nutrió de hijos de bienhechores y acólitos de los PP. capuchinos. Será un centro de enseñanza religioso moderno, tanto en las materias impartidas como en los medios de que disponía para el aprendizaje, con gabinetes científicos, talleres de arte y música y, desde el primer momento, laboratorio de fotografía.

Tras siete cursos de formación, en 1900 Pedro Satué recibe el hábito capuchino, adoptando el nombre de Fr. Pedro María de Madrid, y un año después ya es fraile corista, denominación derivada de la obligación de asistir al rezo del Oficio Divino en el coro, a la par que sirve al Colegio como profesor del taller de dibujo y pintu$\mathrm{ra}^{17}$. En 1904 realiza la profesión perpetua como fraile capuchino ${ }^{18}$, y en 1906 es ordenado sacerdote en el transcurso del solemne Triduo de aniversario por la beatificación de los misioneros capuchinos Agatángelo y Casiano, acto presidido por un cuadro de los beatos pintado por él que fue muy elogiado ${ }^{19}$.

Las aptitudes artísticas de Fr. Pedro de Madrid no pasaron desapercibidas a los responsables del Colegio, máxime cuando en Lekaroz se cuidaba con esmero la cualificación de sus frailes en aquellas materias en las que sobresalían, fuesen científicas, técnicas o artísticas. Además, en este caso el estímulo venía reforzado por prescripción facultativa, dado que Fr. Pedro padecía una enfermedad neurológica crónica (neuro-artritismo con episodios de crisis nerviosas y de ansiedad) que aconsejaba el desempeño de actividades más tranquilas, como las artes ${ }^{20}$. Por tal motivo, durante el período de dedicación plena a Lekaroz, que se extiende desde el verano de 1907 hasta el otoño de 1912, supo armonizar las obligaciones religiosas y la actividad docente con el desarrollo de sus inquietudes artísticas. Entre éstas se encontraba la música, dado que, además de tener condiciones para el canto, tocaba con soltura el contrabajo y el violonchelo, acompañando con suma frecuencia las funciones religiosas más

${ }^{17}$ El 7-1-1900 el P. Llevaneras impuso el hábito de novicio a un grupo de postulantes, entre ellos "al joven Pedro Satué y Blanco, de 20 años de edad, natural de Madrid". Archivo Conventual de Lekaroz (ACL). Actas de imposición del Sto. Hábito capuchino a los novicios del Distrito de Madrid y Misiones de Ultramar, $\mathrm{n}^{\mathrm{o}}$ 72: 36. El 20-1-1901 Fr. Pedro de Madrid realiza la profesión simple o temporal en la Orden. ACL. Libro de actas de Declaración de voluntad para la profesión [simple, temporal], h. 73 r.

18 Acto de profesión perpetua [solemne] de Fr. Pedro M ${ }^{\mathbf{a}}$ de Madrid. ACL. Profesiones solemnes en Lekaroz, 1891-1968, [asiento] no 72, 24 de enero de 1904.

19 ACL. Crónica del P. Emiliano de Andoáin (C.E.), t. III, domingo 25-martes 27 de febrero 1906: 35-37. Por su parte, el periódico donostiarra La Constancia, 1-3-1906: 1, y la revista El Mensajero seráfico, 1-5-1906: 153, recogen los favorables comentarios dedicados al cuadro de Fr. Pedro de Madrid por el pintor Santiago Arcos.

${ }^{20}$ ACL. Religiosos particulares desde 1902. Carta de Pedro M. de Madrid al Min. Prov. Antonio de Iroz, 4-9-1909. Según un certificado médico que presentará en 1918 al Provincial con el fin de no regresar a Lekaroz, Fr. Pedro padecía la "enfermedad de Krishaber". ACL. Carpeta personal (Pedro Satué Blanco). Certificado médico adjuntado en una Carta de Pedro de Madrid al Min. P. Provincial Antonio de Iroz, Sevilla, 16-8-1918. 
solemnes, así como las veladas literarias y musicales en las que participaba como solista y cantante de zarzuela.

Más relevante resultó si cabe su papel como dibujante y pintor $^{21}$, disciplinas en las que con casi toda seguridad tuvo su primer contacto con Fr. Antonio de Vera ${ }^{22}$, responsable del taller de escultura, y quizás también con el pintor aragonés Ramiro Ros Ráfales, quien entre 1896 y 1898 pasó varias temporadas en Lekaroz realizando encargos como el ciclo sobre la vida de San Francisco de Asís, la galería de retratos de ilustres capuchinos y el Via $\mathrm{Crucis}^{23}$. Siguiendo la política de formación continua característica del centro, Fr. Pedro de Madrid llevará a cabo sucesivas estancias fuera de Lekaroz, en su caso con el propósito de mejorar su capacidad pictórica. Así, permanece durante el curso 1904-1905 en Madrid, recibiendo clases de un maestro pintor $^{24}$ y ejecutando diversos retratos al óleo con destino al Colegio, entre ellos los del Papa Pío X, el P. General de los Capuchinos Fr. Bernardo de Andermatt, y el P. Llevaneras ${ }^{25}$. Desgraciadamente, su estancia madrileña coincidirá con el fallecimiento de su madre en 1905, a los 52 años de edad.

De vuelta a Lekaroz, se reincorpora al plantel de profesores, al taller de dibujo y pintura, y al gabinete de fotografía. Al inicio del curso 1906-1907 retorna a Madrid, esta vez a realizar copias de pinturas del Museo del Prado, viaje que volverá a repetir en el otoño de 1912, permaneciendo en esta ocasión por espacio de tres años, durante los cuales residirá en los conventos de El Pardo y de Jesús de Medinaceli; estas prolongadas estancias fuera del Colegio vinieron también propiciadas por su frágil salud, dado que el húmedo clima baztanés no favorecía la evolución de su enfermedad. En medio de ambos periplos madrileños, y dada la aceptación que habían tenido entre los colegiales sus clases de pintura, en el verano de 1909 solicitó la aprobación para viajar a San Sebastián a perfeccionar sus conocimientos con el prestigioso pintor Santiago Arcos, permiso que le fue denegado, si bien pudo asistir al año siguiente por espacio de dos meses $^{26}$.

\footnotetext{
${ }^{21}$ Quizás sus dotes artísticas le vinieran de familia, por cuanto su hermano Emilio, aunque veterinario militar, también cultivó el dibujo y la escultura; en 1916 mereció el elogio de la prensa madrileña y zaragozana por el monumento que en esta última ciudad levantó al rey Alfonso XIII la quinta región militar, con proyecto de Emilio Satué y ejecución a cargo del escultor Juan Gussoni Buzzi ("El monumento de Zaragoza", Heraldo Militar, 25-1-1916: 2; "Un monumento al Rey en Zaragoza", Blanco y Negro, 30-1-1916: 35). Destinado ese mismo año al norte de África, alcanzó relevancia como dibujante colaborador del periódico melillense El Telegrama del Rif. Por su parte, su hermana Carmen fue una prestigiosa modista sumamente conocida en Madrid por el diseño de sombreros.

${ }^{22}$ Fr. Antonio de Vera (1852-1942) fue un prolijo escultor de la orden, como lo demuestra la cantidad de imágenes que realizó para numerosos conventos (Zudaire Huarte 1989: 101).

${ }^{23}$ De la presencia y encargos de Ros Ráfales en Lekaroz da noticia La Avalancha, no 30, 8-71896: 68. Sus cuadros, que decoraban dos galerías del Colegio, se encuentran actualmente en la Sala Lekaroz del convento de capuchinos de Sangüesa, habilitada el año 2003.

${ }^{24}$ ACL. Crónica del P. Berardo de Cieza. Letra "E" (años 1904-1905), 9-02-1905, fol. 42v. Lástima que el P. Cieza no señale el nombre del pintor docente.

${ }^{25} \mathrm{Su}$ envío a Lekaroz va acompañado de instrucciones precisas del lugar que deben ocupar en función de la iluminación de las salas, lo cual nos habla de un artista cuidadoso hasta en los mínimos detalles.

${ }^{26}$ En una primera carta redactada en Lekaroz el 22-8-1909, Fr. Pedro propone al P. Provincial Antonio de Iroz residir en el convento de Fuenterrabía durante las vacaciones y acudir desde
} 
En el verano de 1915 regresa a Lekaroz, dando por concluida su etapa formativa madrileña, pero no sus estancias fuera del Colegio. A finales de año será enviado a tierras andaluzas "con objeto de copiar para este Colegio algunos cuadros de pintores célebres", refiere el rector de Lekaroz, Fr. Joaquín $\mathrm{M}^{\mathrm{a}}$ de Beriain ${ }^{27}$; además, el clima del sur resultaba aconsejable para su enfermedad. Aunque por obediencia marchó a Andalucía, su verdadero interés era volver a Madrid, pretensión que dará origen a diversos conflictos con sus superiores en los años siguientes ${ }^{28}$. En los conventos de Córdoba y Sevilla permanecerá hasta el momento de su regreso a Navarra en el verano de 1918, trabajando intensamente en la copia de cuadros de Murillo, en los que demuestra su capacidad como copista del pintor sevillano puesta de manifiesto en el manejo de la luz ${ }^{29}$.

A la música y pintura debemos añadir su interés por la fotografía, en cuya técnica se inició de la mano de Fr. Antonio de Antequera ${ }^{30}$, pionero y responsable del laboratorio de fotografía de Lekaroz, aprendiendo ya desde novicio a preparar químicamente las placas, realizar las tomas, y revelar y retocar las imágenes ${ }^{31}$. Aunque en el Colegio nunca existió el cargo "oficial" de fotógrafo, de forma oficiosa siempre hubo un responsable del laboratorio, encargado de obtener e impresionar placas, muchas de ellas para ser editadas como tarjetas postales y prospectos promocionales. Esta labor

$\overline{\text { allí a San Sebastián }}$ para recibir clases. Ante la negativa de éste, en una segunda misiva no acierta a explicarse, con cierto tono irónico, los motivos por los que se le impide perfeccionar sus conocimientos pictóricos con Santiago Arcos, "artista de los mejores de España, muy galardonado, católico ferviente, expulsado de Francia, actualmente residente en San Sebastián", lo que en su faceta de copista y profesor redundaría en beneficio del Colegio. Finalmente, al año siguiente se le dio autorización para permanecer en la residencia de San Sebastián durante agosto y septiembre y trabajar con el pintor. ACL. Religiosos particulares desde 1902. Carta de Pedro M. de Madrid al Min. Prov. Antonio de Iroz, Lekaroz, 4-9-1909; y Carta de Pedro M. de Madrid al Min. Prov. Antonio de Iroz, San Sebastián, 3-9-1910.

${ }_{27}$ Carta del P. Rector del Colegio de Nuestra Señora del Buen Consejo de Lecároz, 19-2-1917. Archivo de la Institución Príncipe de Viana (AIPV). Leg. 2/25. Año 1917.

${ }^{28}$ En abril de 1917 solicitó licencia para trasladarse a Madrid, que no le fue concedida, aunque sí su marcha a Sevilla. A principios de 1918 se traslada a Madrid por un tema familiar sin permiso de sus superiores, pero en abril está de nuevo en Sevilla. ACL. Carpeta personal (Pedro Satué Blanco). Copia de una Carta-respuesta al General de la Orden, P. Venancio de Lisle-en-Rigault al P. Pedro de Madrid, Roma, 3-4-1918.

${ }^{29}$ Entre las copias de Murillo se encuentran el San Francisco abrazando a Cristo, las dos versiones de San Antonio de Padua y el Niño, y la Virgen de la servilleta, todos ellos del Museo de Bellas Artes de Sevilla. Tras el cierre del Colegio de Lekaroz, estos y otros lienzos de Fr. Pedro de Madrid se custodian en la iglesia de San Antonio de capuchinos de Pamplona, y en el convento de capuchinos de Sangüesa.

${ }^{30}$ Fr. Antonio de Antequera (1854-1937), polifacético colaborador del P. Llevaneras en Lekaroz, fue responsable de la contaduría, provisiones, laboratorio fotográfico y portería (Zudaire Huarte 1989: 56 y 100-101).

${ }^{31}$ El colegio de Lekaroz dispuso desde sus comienzos de un avanzado taller de fotografía, con cámaras y lentes de la marca alemana Carl Zeiss, placas y negativos de cristal de la casa Bonne Presse de París, y un amplio laboratorio compuesto de tres estancias para cámara lenta, el revelado en todas sus fases, en mate y en brillo, en cristal y papel. Todo un símbolo de modernidad en la Navarra rural de entresiglos (Azcona 2011: 397-414). Por las facturas conservadas en el archivo del Colegio se constata la adquisición de todo tipo de material fotográfico en establecimientos de Barcelona (Casa Riba), Bilbao (Casa Espiga, Casa Lux), Zaragoza, etc. 
fue desempeñada por Antequera en los primeros años del centro, hasta que su marcha en 1908 propició que Fr. Pedro de Madrid recogiera el testigo al frente del laboratorio. Como fotógrafo "oficial", impresionó numerosas placas del Colegio (aulas, laboratorios, iglesia, vistas generales), así como fotografías de la comunidad de religiosos y colegiales (retratos individuales y colectivos, eventos, excursiones); y no sólo de Lekaroz, sino también del resto de conventos de la Provincia Capuchina ${ }^{32}$. Por su carácter periodístico y documental, destacan las realizadas en marzo de 1912 con motivo de una multitudinaria concentración de baztaneses en el Colegio por la clausura de unas misiones, así como las publicadas en Diario de Navarra el 12 de junio de ese mismo año ilustrando un reportaje sobre el centro ${ }^{33}$. Aunque la mayoría son testimonio de personas y acontecimientos, el talante más artístico que artesanal de Fr. Pedro le llevará a ampliar su horizonte e, influenciado por el pictoralismo fotográfico, a crear composiciones narrativas.

Fueron precisamente este interés artístico por la fotografía, y el carácter social de los temas propuestos que obligaba a presentar trabajos más creativos, los motivos que le impulsaron a participar en el certamen pamplonés. El tema V del concurso, dedicado a los caseríos vascos, le movió a recorrer los pueblos y barrios del Valle de Baztán en plena primavera de 1912, impresionando placas de los caseríos y de sus habitantes ocupados en sus labores cotidianas. Con todo el material que conforma la serie, hizo una selección de veinticuatro fotografías que presentó al certamen bajo el lema Echezarra (Casa vieja). Su colección fue muy elogiada, logrando dos de los galardones más importantes: primer premio en la categoría de caseríos vascos (250 pesetas), y primer premio especial para aficionados (200 pesetas).

Con ser significativa la cuantía económica de los premios, Fr. Pedro obtuvo una recompensa de mayor trascendencia para su posterior trayectoria vital: cierta resonancia artística y social. En efecto, algunas revistas ilustradas del momento se hicieron eco del certamen y, en especial, del triunfo del capuchino, con elogiosos comentarios hacia su obra. Es el caso de La Hormiga de Oro y de La Ilustración Española y Americana, que publicaron sendos reportajes gráficos con la firma de José Roldán que reproducían los caseríos y el retrato de su autor ${ }^{34}$. A las anteriores debemos sumar las noticias aparecidas en La Baskonia ${ }^{35}$, Novedades ${ }^{36}$ y La Avalancha, en esta última en sucesivos números de 1913 y 1914, ilustrados con cinco fotografías regaladas por el propio religioso ${ }^{37}$.

Asimismo, la colección despertó el interés de diversas instituciones culturales, caso del Museo Municipal de San Sebastián (actual San Telmo), el cual en 1916, y a peti-

\footnotetext{
${ }^{32}$ En 1910, el Provincial P. Antonio de Iroz le encargó un reportaje fotográfico de todos los conventos de la Provincia. ACL. Religiosos particulares desde 1902. Cartas de Pedro M. de Madrid al Min. Prov. Antonio de Iroz, Lekaroz, 12-6-1910, 22-6-1910, 3-7-1910.

33 "Ecos del Baztán. Misiones en Elvetea, Maya y Elizondo", Diario de Navarra, 22-3-1912: 1; "El Colegio de Capuchinos de Lecároz", Diario de Navarra, 12-6-1912: 1.

${ }^{34}$ La Hormiga de Oro, no 33, 17-8-1912: 521. La Ilustración Española y Americana, n ㅜ 31, 228-1912: 112.

${ }^{35}$ La Baskonia, no 690, 30-11-1912: 111. La revista, editada en Buenos Aires en torno a la EuskalEtxea y a la emigración vasca, publica un interesante artículo en el que no escatima elogios para Fr. Pedro de Madrid.

${ }^{36}$ Novedades, nำ 187, 19-1-1913: 13; y no 193, 2-3-1913: 11.

37 La Avalancha, no 436, 9-6-1913: 130; nํ 439, 24-7-1913: 167; no 441, 23-8-1913: 190-191; no 443, 24-9-1913: 215; y no 457, 8-5-1914: 103.
} 
ción de su secretario, el etnógrafo José Aguirre López, recibió de la comunidad capuchina de Lekaroz "una interesante colección etnográfica de fotografías de caseríos y jaureguís de las montañas de Navarra", que la Junta del Museo agradeció en carta oficial $^{38}$. A finales del mismo año, la Comisión de Monumentos Históricos y Artísticos de Navarra solicitó al Colegio una colección de fotografías de los caseríos, apelando a su interés por "contribuir al estudio de la Historia y el Arte patrios, y, en particular, a las peculiaridades de esta provincia de Navarra ${ }^{39}$. Habiendo sido informados por el rector Fr. Joaquín $\mathrm{M}^{\mathrm{a}}$ de Beriain de que los clisés los tenía Fr. Pedro de Madrid ${ }^{40}$, el vocal y fotógrafo Julio Altadill se desplazó hasta Córdoba, donde el capuchino le hizo entrega de doce copias en papel de otros tantos caseríos del álbum premiado ${ }^{41}$. También por estas mismas fechas sus fotografías contribuirán a la elaboración del Catálogo Monumental y Artístico de la Provincia de Navarra, redactado por Cristóbal de Castro $^{42}$, y participará en diversos concursos fotográficos, llegando a obtener otro primer premio ${ }^{43}$.

No debemos pasar por alto un detalle relevante para el futuro devenir de nuestro protagonista: la propiedad de los clisés no es del Colegio de Lekaroz, sino del capuchino ganador del concurso. El interés mediático que despertó la colección premiada hará que Fr. Pedro de Madrid tome conciencia de la condición de fotógrafo y de la calidad de su trabajo y, por ello, llevará consigo los clisés en sus estancias en Madrid y en Andalucía.

El reconocimiento adquirido como fotógrafo, su vitalidad artística que requería espacios más abiertos que los muros de un convento, los años de formación y trabajo fuera de Lekaroz en mayor contacto con la sociedad civil y los roces con sus superiores de la Provincia, pesaron sin duda en su decisión, en un primer momento,

${ }^{38}$ Carta de la Comisión de Etnografía Vasca del Museo Municipal de San Sebastián. San Sebastián, 17-11-1916. ACL. Letra L-no 44. En el acta del 29 de diciembre, la Junta de Gobierno del Museo hace constar el donativo recibido. Museo San Telmo. Libros de Actas, Lib. 4, 29 de Diciembre de 1916.70 Sesión de la Junta de Gobierno del Museo Municipal, hs. 46, 48r, 50r, 57r. En la carta oficial de agradecimiento de 31 de diciembre, se indican al margen las piezas donadas. Carta de la Junta de Gobierno del Museo Municipal de San Sebastián. San Sebastián, 30-12-1916. ACL. Letra L-nº 46. En el Museo San Telmo hemos localizado dieciséis fotografías de Fr. Pedro de Madrid de la serie "Caseríos vascos" donadas por la comunidad de Lekaroz, de las que nueve forman parte de la colección premiada, y el resto de las no seleccionadas. En el Catálogo del Museo figuran como anónimas, de cronología incierta y procedencia desconocida; y aunque la mayoría están localizadas en Baztán, en muy pocos casos se identifica el lugar y caserío fotografiado.

39 Carta de la Comisión de Monumentos del Museo Arqueológico al P. Rector. Pamplona, 24-11917. ACL. Letra L, nำ 48. Boletín de la Comisión de Monumentos Históricos y Artísticos de Navarra, T. 8, no 29, 1917: 5-7.

${ }^{40}$ Carta del P. Rector del Colegio de Lecároz, 19-2-1917. AIPV. Leg. 2/25. Año 1917.

${ }^{41}$ Boletín de la Comisión de Monumentos Históricos y Artísticos de Navarra, T. 8, no 30, 1917 : 84-90.

42 "A los centenares de fotografías hechas expresamente para nosotros por nuestro fotógrafo Miguel España, hemos podido sumar las que adquirimos de los señores Lacoste, Roldán, Pliego y Mena, y las que generosamente nos fueron cedidas por los señores Altadill, Etayo, Ansoleaga y P. Pedro de Madrid" (Castro 1916-18: 9).

43 Desconocemos cuál fue el concurso en el que resultó nuevamente premiado. La noticia nos la proporciona el propio Fr. Pedro de Madrid en una carta escrita en 1919 al Obispo de MadridAlcalá. 
de vincularse a la Provincia de Andalucía y finalmente, de abandonar la fraternidad capuchina, comunicada a sus superiores en 1918. Influyeron igualmente su frágil salud ante el húmedo clima baztanés y algunas circunstancias familiares - la muerte de su hermano Emilio y la soledad de su hermana Carmen-, tal y como hacía saber en dos cartas dirigidas al Obispo de Madrid-Alcalá en junio de $1919^{44}$.

El 1 de septiembre de 1919, tras medio año en el convento de Tudela a la espera de su exclaustración, regresa a la vida secular, recuperando su nombre civil: Pedro Satué Blanco. Deja de ser fraile, aunque no su condición de sacerdote ${ }^{45}$, y se incorpora de forma temporal a la Diócesis de Madrid-Alcalá, estableciéndose en el domicilio de su hermana en la calle Bárbara de Braganza, donde ésta regentaba una sombrerería y salón de moda. Aprovechando sus conocimientos fotográficos, pronto encuentra trabajo en la revista La Estrella del Mar, órgano de las Congregaciones Marianas editada por los jesuitas, a la vez que comienza a invertir en material fotográfico profesional ${ }^{46}$. Se inscribe como socio en la Real Sociedad Fotográfica de Madrid $^{47}$ y no tarda en publicar algunas fotografías con la firma "Fot. Satué" en $A B C$, Blanco y Negro y La Esfera. Se trata por lo general de retratos y noticias gráficas de eventos religioso-culturales de la alta sociedad madrileña, material entre el que sobresale un magnífico retrato de cuerpo entero de Alfonso XIII contemplando el Campo del Moro desde los balcones del Palacio Real incluido en La Esfera $(1920)^{48}$.

En la primavera de 1924, una vez su situación eclesiástica parece estabilizarse tras ser admitido por el Patriarca de las Indias entre los presbíteros de la Real Capilla ${ }^{49}$,

${ }^{44}$ Desde Tudela, Fr. Pedro de Madrid enviará al Obispo D. Prudencio Melo dos cartas fechadas el 16 y 28 de junio de 1919 en las que expone su situación y solicita ser admitido como sacerdote en la Diócesis. En ambas destaca, a modo de presentación, la actividad docente y artística desarrollada en Lekaroz ("dicho Colegio está lleno de cuadros míos", afirma), y para justificar su marcha del mismo pone el acento en sus problemas de salud y en la orfandad de su hermana Carmen. Carta de Fr. Pedro de Madrid dirigida al Sr. Obispo de Madrid-Alcalá. Tudela, 16-6-1919; y Tudela, 28-6-1919. Archivo Histórico Diocesano de Madrid (AHDM). Caja sign. 24646/ 42. Expediente de D. Pedro Satué.

${ }^{45}$ En 1921 ejerce como sacerdote adscrito a la iglesia de San Pascual de Madrid; como tal figura en una lista de suscriptores en ayuda a unos niños huérfanos tras una tragedia acaecida pocas fechas antes. "Homenaje nacional", $A B C$, 19-6-1921: 17.

${ }^{46}$ Su nueva situación queda reflejada en la carta enviada al Obispo el 1-9-1920 solicitando la ampliación del permiso para ejercer el ministerio sacerdotal en la Diócesis. Significa en la misma que "me encuentro muy bien y contento, trabajando por la buena prensa, prueba de que ésta era la voluntad de Dios". Carta de D. Pedro Satué al Sr. Obispo de Madrid-Alcalá. Madrid, 1-91920. AHDM. Caja sign. 24646/42. Expediente de D. Pedro Satué.

${ }^{47}$ En 1922 utilizó el laboratorio de la Real Sociedad Fotográfica en 54 ocasiones, siendo el segundo socio que hizo un mayor uso de él (Martín López y Muñoz García 2004: 48).

48 "Una fotografía del Rey", La Esfera, nº 344, 7-8-1920: 24. Sánchez Vigil, en su exhaustiva tesis sobre la documentación gráfica de La Esfera, incluye una breve referencia a Satué, situándolo entre los fotógrafos vascos, en torno a la Casa Lux; mas no llega a relacionarlo con Fr. Pedro de Madrid, ni con la posterior firma fotográfica Antsa (Sánchez Vigil 1995: 305). Referencias del mismo autor a Satué y Antsa en Sánchez Vigil (2003: 338 y 361).

${ }^{49}$ Habían ido pasando los años sin que Pedro Satué solicitara a Roma el indulto de exclaustración definitivo, documento imprescindible para legalizar su situación canónica. Gracias a las gestiones llevadas a cabo por el Conde de Azara, en 1924 el Patriarca de las Indias lo admitirá entre los presbíteros de la Real Capilla, cargo que le dotó de la estabilidad necesaria para iniciar la tramitación del permiso permanente de exclaustración y que, además, le dejaba el suficiente 
Satué dará el salto definitivo a la fotografía profesional con la apertura de un estudio con el nombre comercial de Antsa, acontecimiento del que daba noticia La Época ${ }^{50}$. El gabinete fotográfico quedó instalado en un edificio recién construido en la Avenida de Peñalver 19 (actual Gran Vía 8), esquina con Víctor Hugo, zona céntrica y comercial en proceso de expansión ${ }^{51}$, y comprendía no sólo el laboratorio, sino también una sala para las tomas y otra de exposición de pinturas y fotografías. Cabe pensar que la elección del nombre fuera un pequeño homenaje a sus años vividos en Lekaroz, por cuanto "Antza" significa en euskera "semejanza, parecido, apariencia", lo cual puede interpretarse como un guiño a la condición de la fotografía, y más concretamente del retrato, faceta que constituirá la base económica de su negocio. A partir de esos momentos, simultaneará su labor como retratista particular de la alta sociedad madrileña ${ }^{52}$ con colaboraciones gráficas en algunas revistas; permanece vinculado a $L a E s$ trella del Mar (en la que mantiene la firma "Fot. Satué"), y publica de forma puntual en Blanco y Negro y La Lectura Dominical (como "Fot. Antsa). Siguen siendo noticias gráficas de actos culturales, composiciones de escenas o retratos de grupo, y reportajes de celebraciones religiosas.

Hacia 1928 observamos un incremento de sus colaboraciones en la prensa gráfica y, lo que supone una mayor novedad, en publicaciones de temática e ideología mucho más variada, entre las que se encuentran Estampa, La Voz, Nuevo Mundo, Muchas Gracias, Blanco y Negro, La Esfera y Mundo Gráfico. Las fotografías publicadas son en su mayoría encargos específicos de sus editores, buena parte de ellos retratos. Considerado a sí mismo un fotógrafo artístico — tal es así que en ocasiones firma como "Fot. de Arte Antsa", al igual que lo hacen otros fotógrafos y estudios como Calvache y Walken-, destacará por la depurada técnica pictórica en el manejo de la luz que aplica a los diversos tipos de planos del retrato fotográfico; de hecho, en 1927 el establecimiento se anunciaba en La Época como especialista en aplicar a las fotografías efectos de luz a imitación del cine, así como en mantener los colores reales ${ }^{53}$.

No obstante, en esta nueva etapa como Antsa, y paradójicamente a su condición de sacerdote y propagandista católico, Satué nos presenta otra faceta profesional vinculada al mundo del espectáculo, al ambiente teatral y de la revista madrileña, especializándose en retratos artísticos de cantantes, actrices y cupletistas. Probablemente

tiempo para dedicarse a la fotografía. Carta de D. Pedro Satué al Secretario de Cámara del Obispado. Madrid, 16-3-1924. AHDM. Caja sign. 24646/42. Expediente de D. Pedro Satué.

${ }^{50}$ Una noticia-anuncio informaba de la apertura por parte del "distinguido sacerdote y artista don Pedro Satué" de un "gran estudio de fotografía con el nombre de Antsa", en el que se exhibe "una caprichosa colección de retratos a colores" y también "tablas al óleo". La Época, 29-51924: 2. El anuncio se repite dos días más tarde.

51 "Gran Vía, n 8. Entre 1913 y 1917, construyó el arquitecto Francisco Pérez de los Cobos esta casa para el empresario José Antonio Becerril, dedicada a casa de renta... En 1919 se realizaron reformas de ampliación del edificio. Fue éste el primer edificio que se terminó y luce ya en las primeras fotografías de la entonces naciente y todavía muy incompleta Gran Vía... llamada desde un principio a ser una avenida comercial" (Corral 2002: 138).

${ }^{52}$ En febrero de 1927 inserta un anuncio en La Época que dice: "¿Quién es el fotógrafo de los niños de la aristocracia? Todo el mundo sabe que es Antsa, Avenida de Peñalver, 19 (entrada por Víctor Hugo). Teléfono 15.956". La Época, 24-2-1927: 2; y 26-2-1927: 2.

53 La Época, 18-3-1927: 3. 
personajes como José Campúa ${ }^{54}$, conocedores de su valía profesional, le animaron a introducirse en esta faceta, a lo que debió de contribuir también la estratégica ubicación de su estudio cerca de varios teatros y salas de espectáculos que le permitió captar a través de su objetivo ese "Madrid frívolo" de los años veinte y comienzos de los treinta (panorama que describe con precisión Montijano Ruiz 2013: 64-105).

No es momento ahora de enumerar la totalidad de sus colaboraciones fotográficas. Sirvan como referente de la calidad de sus trabajos los retratos de una jovencísima Celia Gámez en Estampa (1928) ${ }^{55}$ y Muchas Gracias $(1929)^{56}$, así como de la actriz María Guerrero López en $A B C$ y Blanco y Negro (1931) ${ }^{57}$. Junto a ello, las fotografías sobre "ecos de sociedad" y eventos culturales exclusivos seguirán ocupando un apartado importante en su actividad; destaca por la fuerza de la imagen y su carácter pictórico el retrato de los hermanos Álvarez Quintero para Estampa (1928) ${ }^{58}$.

La última fotografía de Antsa que conocemos data de diciembre de 1932; se trata de un retrato coloreado de la actriz Josefina Tapias que publica $A B C$ como portada del suplemento dominical ${ }^{59}$. A partir de esta fecha, su rastro, tanto eclesiástico como fotográfico, se pierde de forma abrupta. Conociendo su enfermedad neurológica y los antecedentes familiares de muertes tempranas, cabe la posibilidad de un fallecimiento prematuro; sorprende sin embargo que, de haber sido así, la prensa no se hiciera eco de la luctuosa noticia. Pudiera conjeturarse también con un agravamiento de su enfermedad que le obligara a algún tipo de internamiento. Otra explicación es que abandonase Madrid, en plena efervescencia republicana anticlerical, en busca de lugares más tranquilos para un sacerdote y artista, aunque cuesta creer que dejara de lado todo el empeño puesto en su gabinete fotográfico. Sea como fuere, y a la espera de futuras vías de investigación que aporten nuevos datos, el hecho cierto es que desde ese momento nada más conocemos de este polifacético personaje, fraile capuchino durante casi veinte años, músico, pintor y fotógrafo de Lekaroz, y fotógrafo profesional al frente de su propio establecimiento en Madrid, especializado en retratos artísticos y colaborador de las revistas gráficas más importantes de la época.

\section{ECHEZARRA: UNA COLECCIÓN FOTOGRÁFICA INÉDITA}

La presencia de Fr. Pedro de Madrid en Lekaroz coincide con la aparición, en los primeros años del siglo XX, de innovaciones en el campo de la fotografía. Además,

\footnotetext{
${ }^{54}$ José Demaría López (1870-1936), conocido como José Campúa, fue reportero gráfico de Nuevo Mundo y La Esfera, y fundador y director de Mundo Gráfico; también es conocida su labor como fotógrafo y cronista de Alfonso XIII, por la que el monarca lo nombró Fotógrafo de la Casa Real. En su faceta de empresario teatral, regentó el local Madrid Cinema o Teatro Maravillas, promocionando a artistas de la talla de María Conesa, Celia Gámez o Raquel Meller (Sougez y Pérez Gallardo 2009: 104-105).

55 "Celia Gámez, la bellísima vedette de Eslava", Estampa, no 2, 10-1-1928: 11.

56 "Celia Gámez, ídolo del público", Muchas Gracias, nº 164, 26-3-1929: 10. La entrevista la firma el periodista y guionista de cine Alejandro Núñez Alonso, quien, tras elogiar la calidad de los retratos, otorga "al gran artista Antsa la condición de "elegante fotógrafo de Celia Gámez". Así debió de ser, pues en la biografía de la cantante (García Carretero 2010) se incluyen varias fotografías de la década de 1920 que llevan su firma.

${ }^{57}$ ABC, 26-2-1931: 17; Blanco y Negro, 1-3-1931: 47.

${ }^{58}$ Estampa, no 6, 7-2-1928: 19-20.

59 "Actrices españolas. Josefina Tapias", $A B C$, 4-12-1932: 17.
} 
debido a sus estancias en Madrid, el capuchino conocía cuanto se realizaba por aquellas fechas en España en materia de documentación fotográfica; diversas instituciones, tanto públicas como privadas, habían encargado a fotógrafos la edición de catálogos del patrimonio histórico monumental de cada región. La generalización de la fotografía, junto con estos trabajos de inventariado, explica que la convocatoria de un concurso fotográfico de naturaleza social incentivara al fraile para dar a conocer los lugares y modos de vida representativos del Valle de Baztán, máxime al disponer el Colegio de los medios necesarios para llevar a cabo el proyecto.

En efecto, el centro educativo contaba con un laboratorio y la industria hacía llegar a cualquier parte las placas de gelatinobromuro de plata que simplificaban notablemente la toma fotográfica. Estas placas, en el caso que nos ocupa de cristal y tamaño de $18 \times 24 \mathrm{~cm}$., eran cargadas en chasis de madera para su traslado y posterior uso; no era necesario sensibilizar cada vidrio momentos antes de la impresión, sino que, al comercializarse en seco, permitían la obtención de varias fotografías en una misma sesión. En esos mismos años se introduce con éxito, desbancando al papel a la albúmina, el papel baritado o de gelatinobromuro, que facilitaba la labor del laboratorio y abarataba los costes de producción; sobre el papel se colocaba la placa de vidrio, y por contacto se procedía a su insolación con la simple luz del día. A continuación, en el cuarto oscuro, tenía lugar su revelado químico.

De los anteriores avances se sirvió Fr. Pedro de Madrid en la colección que presentó al certamen, a partir de la cual se elaboró un álbum de doce hojas de $28 \times 37$ $\mathrm{cm}$., con veinticuatro fotografías de $18 \times 24 \mathrm{~cm}$. Al no prosperar la idea del Museo Social Vasco al que como colección premiada estaba destinado, el álbum permaneció en el Colegio de Lekaroz, en tanto que los clisés quedaron en poder del fotógrafo. Actualmente se custodia en el Archivo del convento de capuchinos de Pamplona, donde en abril de 2012 se produjo su redescubrimiento ${ }^{60}$ e identificación; de ahí su carácter inédito ${ }^{61}$, excepción hecha de su publicación parcial en las revistas ilustradas de hace un siglo (entre 1912 y 1921), y con independencia de otras posibles colecciones fotográficas protagonizadas igualmente por caseríos baztaneses, de cronología algo posterior y calidad inferior ${ }^{62}$.

\footnotetext{
${ }^{60}$ Ya en 1988, en un artículo sobre la heráldica baztanesa, el P. Pérez de Villarreal aludía a la existencia e interés de esta colección fotográfica (Pérez de Villarreal 1988: 184).

${ }^{61}$ Otorgamos a la colección carácter inédito en atención a diversos motivos: en primer lugar, once de las veinticuatro fotografías que la componen nunca se han publicado, y de seis de ellas ni siquiera se tiene constancia de la existencia de más copias; además, excepción hecha de los reportajes gráficos de La Hormiga de Oro y La Ilustración Española y Americana en 1912, y de las cinco copias donadas por su autor a La Avalancha en 1913, el resto de caseríos publicados lleva la firma de "Fot. Satué", sin establecer conexión alguna con el origen de las fotografías en el certamen fotográfico-social de Pamplona de 1912, ni con Fr. Pedro de Madrid; por otro lado, en muy pocos casos los pies de fotos identifican el lugar y nombre exacto del caserío, aspecto que tiende a resultar irrelevante frente a la ideología y valores que transmiten, extrapolables a cualquier punto de la geografía vasco-navarra; finalmente, las instituciones que conservan copias fotográficas de la colección de caseríos (Príncipe de Viana, Museo San Telmo, Eusko Ikaskuntza), no llegan a vincularlas con su origen, autor y cronología, y tan sólo puntualmente las localizan en el Valle de Baztán.

${ }^{62}$ Citemos a modo de ejemplo de estas últimas la colección de catorce tarjetas postales procedentes también del Colegio de Lekaroz, editadas y coloreadas por Antonio Echaide (Elizondo, ca. 1921-1922), que bajo el título Euzko-Basetxeak editó hace pocos años el Museo Etnográfico Baztán Jorge Oteiza de Elizondo.
} 
Las veinticuatro fotografías que componen el álbum mantienen una buena estabilidad de imagen y cuentan con una amplia gama de tonos —blancos y negros muy suaves-. Se han visto no obstante afectadas por el foxing, alteración que da lugar a manchas por la oxidación de alguno de los aditivos del papel y que ataca igualmente a la emulsión. El autor demuestra ser buen conocedor de las técnicas fotográficas del momento, incluso de aquéllas utilizadas por los fotógrafos de estudio en las que posteriormente será todo un experto, como el retoque con pinturas y anilinas de las placas de vidrio para la eliminación de detalles que pudieran distraer en la copia final. Varias fotografías del álbum muestran, de hecho, la supresión de montes o zonas boscosas existentes, cuando no de elementos arquitectónicos que, a juicio del autor, no favorecían la presentación última del trabajo; el caso más significativo en este sentido es sin duda Ugaldea de Erratzu, en cuya fotografía se elimina la torre de la parroquia de San Pedro que se avistaba por encima del edificio.

En el álbum, las fotografías vienen identificadas con el nombre y localidad del caserío por medio de una rotulación manuscrita a tinta negra en la parte superior e inferior de cada hoja, que parece ser posterior a la impresión de las imágenes; tan sólo una carece de identificación, si bien incluye una referencia a lápiz —Zubiatea de Gartzain - que no es correcta. Las veinticuatro fotografías corresponden en realidad a veintitrés caseríos, por cuanto de uno de ellos (Iturbidea de Gartzain) captó dos instantáneas con sus fachadas norte y sur. La colección se convierte así en un excepcional ejemplo del hábitat que caracteriza al Valle y Universidad de Baztán, al noroeste de Navarra, que cuenta con un total de quince lugares y numerosos barrios y caseríos dispersos. Todos ellos tienen nombre propio y reconocido, habitualmente invariable a lo largo de la historia; el nombre y solar permanecen unidos sin cambios, mientras que la casa varía su fisonomía al compás de los tiempos, al igual que pueden cambiar también sus propietarios o arrendatarios (Santana y Otero 1993: 7384). En la mayoría de los casos, el oikónimo hace referencia al lugar del emplazamiento; en otros, al nombre o apellido de la familia que lo construyó o habitó (Igoa Moreno 2008: 209). Hemos optado por mantener la denominación con la que se conocía a las casas en 1912, con independencia de los cambios que hayan podido producirse a posteriori; y hemos corregido a su vez los errores detectados en la identificación de cuatro caseríos emplazados en Elizondo, Lekaroz y Ziga ${ }^{63}$.

En su distribución geográfica, comprobamos que nueve caseríos pertenecen a la localidad de Gartzain, convirtiéndose así en la más representada: Etxenikea (casa de Etxenike, Fig. 1), Andalorrea (la pieza del campo, Fig. 2), Iturbidea (casa de los Itúrbide o camino de la fuente, Figs. 3 y 4), Sagardibeltzea (manzanal negro, Fig. 5), Inda (casa de los Inda o de la calleja, Fig. 6), Ugaldegaraia (en la parte de arriba del río, Fig. 7), Lapitzea (casa de Lapitz o de pizarra, Fig. 8), Irunberea (casa de abajo, Fig. 9) y Erreka (regata, Fig. 10). Le sigue Lekaroz, con cuatro: Aldekoa (la de al lado, Fig. 11), Antxoneazarrea (casa vieja de Antso, Fig. 12), Peruenea (casa de Peru, Fig. 13) y Beitiko Xaarrea (casa vieja de abajo, Fig. 14). Se trata, no por casualidad, de las dos poblaciones más cercanas al convento de nuestro capuchino.

${ }^{63}$ El caserío de Elizondo, que en el álbum se denomina Iturriaga, es Zaldarriaga. Un caserío de Lekaroz es identificado como Argiñenea, siendo Beitiko Xaarrea. En cuanto a los dos caseríos de Ziga, los nombres de Goñinea y Landarrea se corresponden en realidad con Arginaga e Iturraldea. 


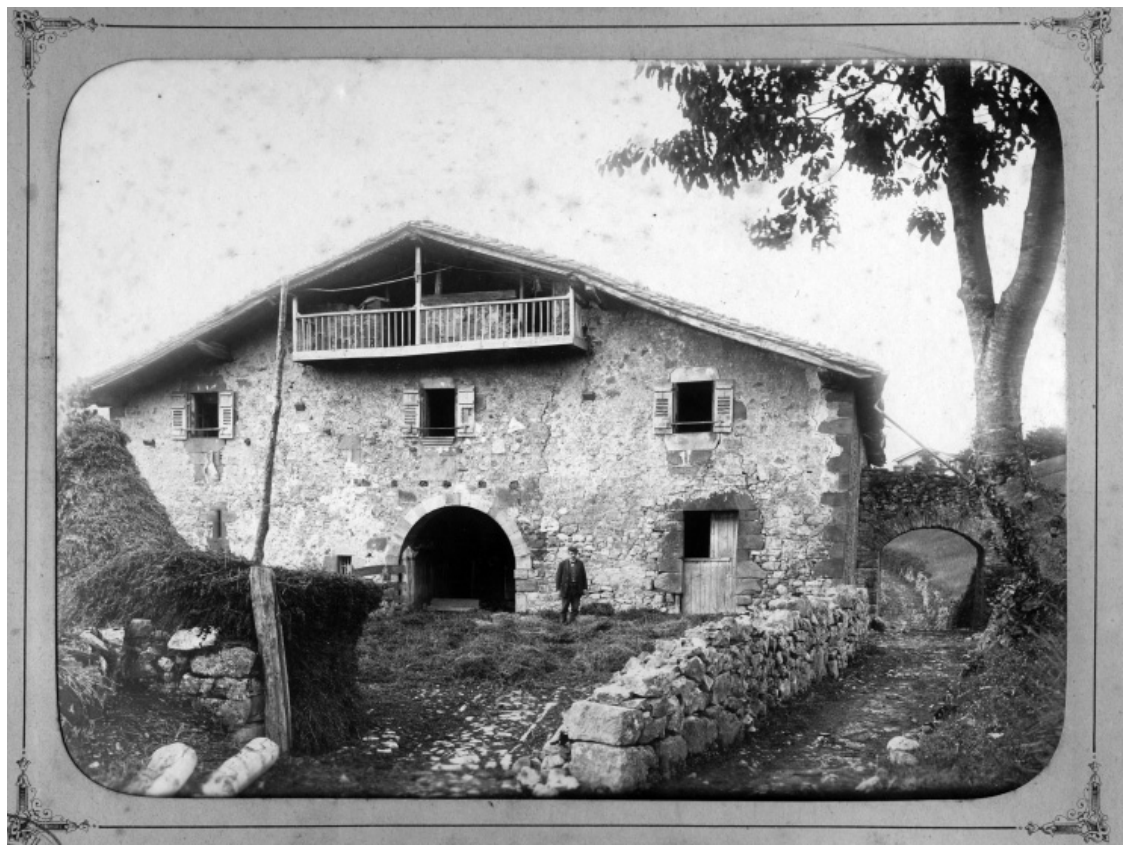

FIGURA 1.-Etxenikea. Gartzain (Valle de Baztán).

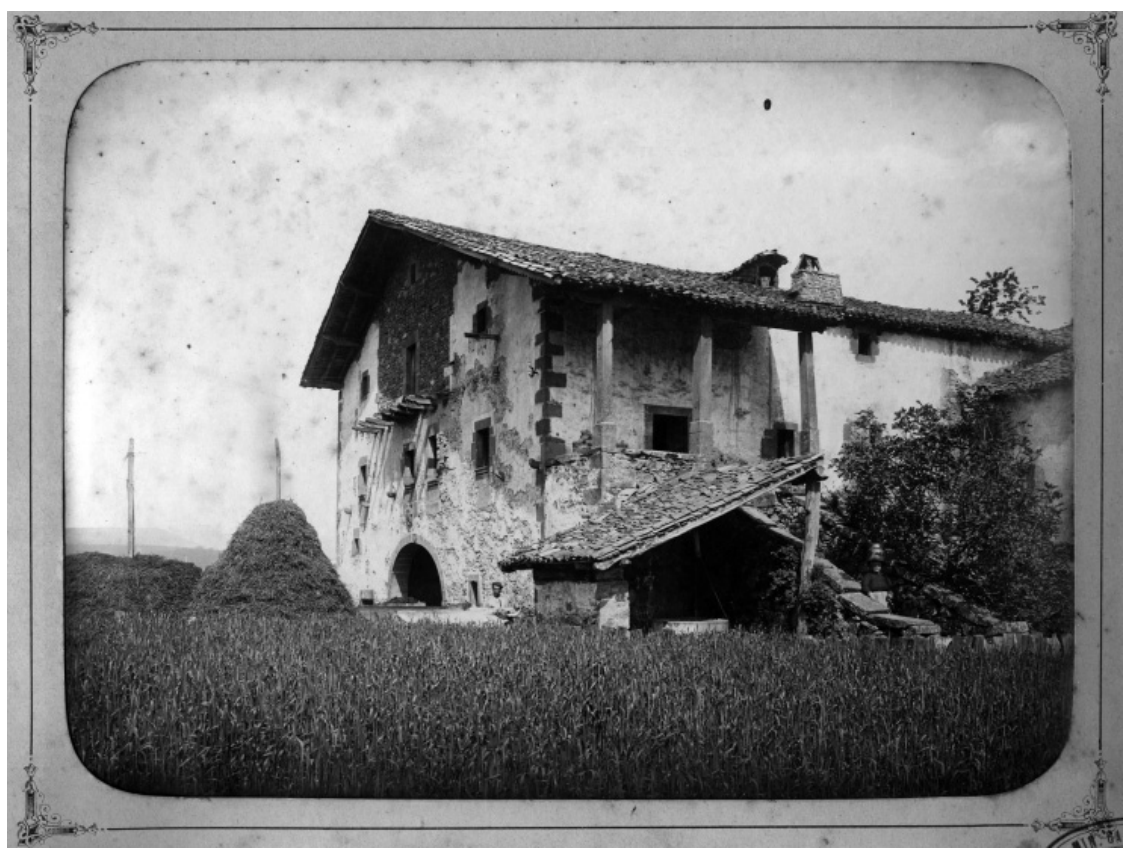

FiguRA 2.-Andalorrea. Gartzain (Valle de Baztán). 


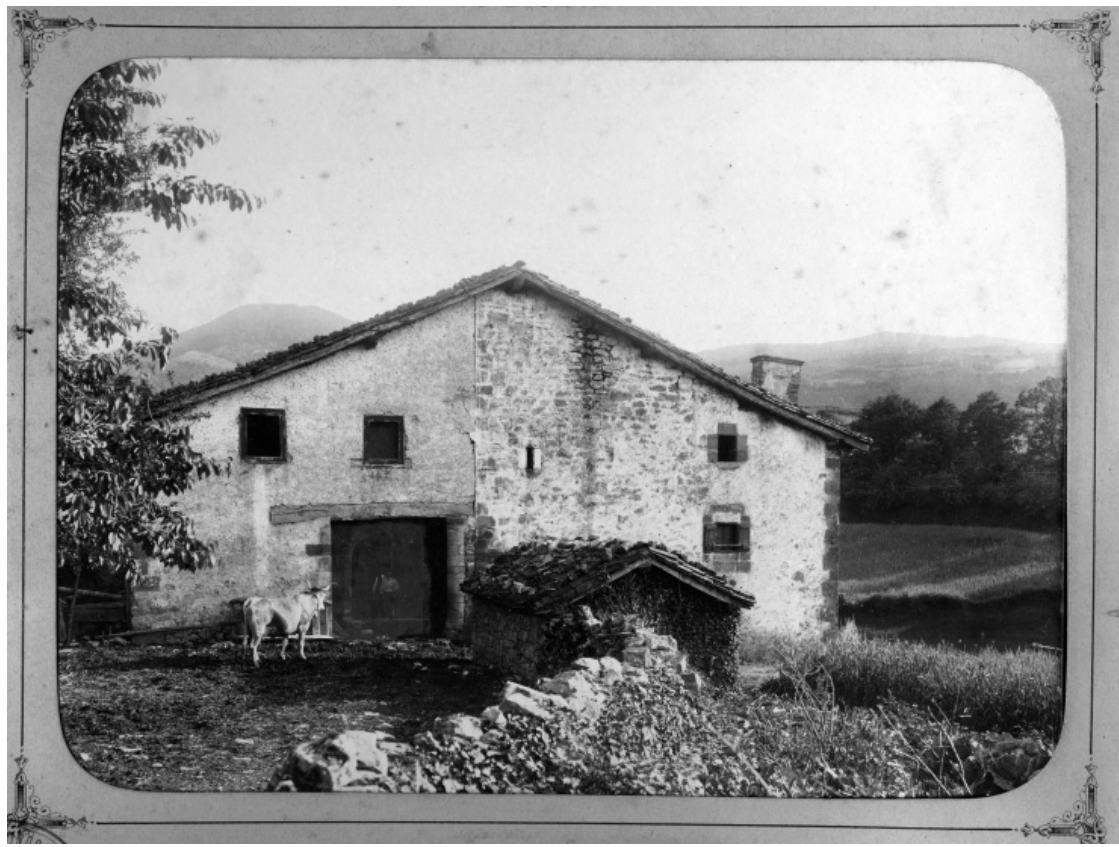

Figura 3.-Iturbidea Norte. Gartzain (Valle de Baztán).

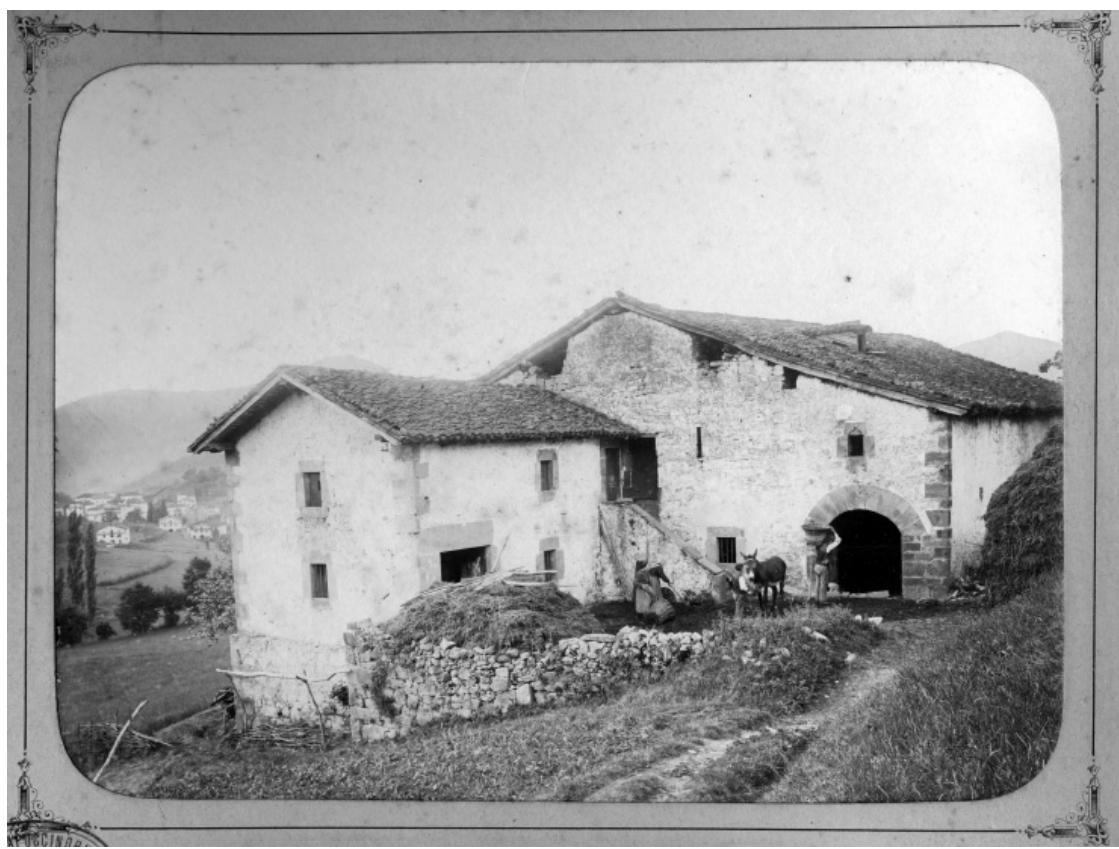

FIGURA 4.-Iturbidea Sur. Gartzain (Valle de Baztán).

Revista de Dialectología y Tradiciones Populares, vol. LXVIII, n. ${ }^{\circ}$ 2, pp. 385-422, julio-diciembre 2013, ISSN: 0034-7981, eISSN: 1988-8457, doi: 10.3989/rdtp.2013.02.016 


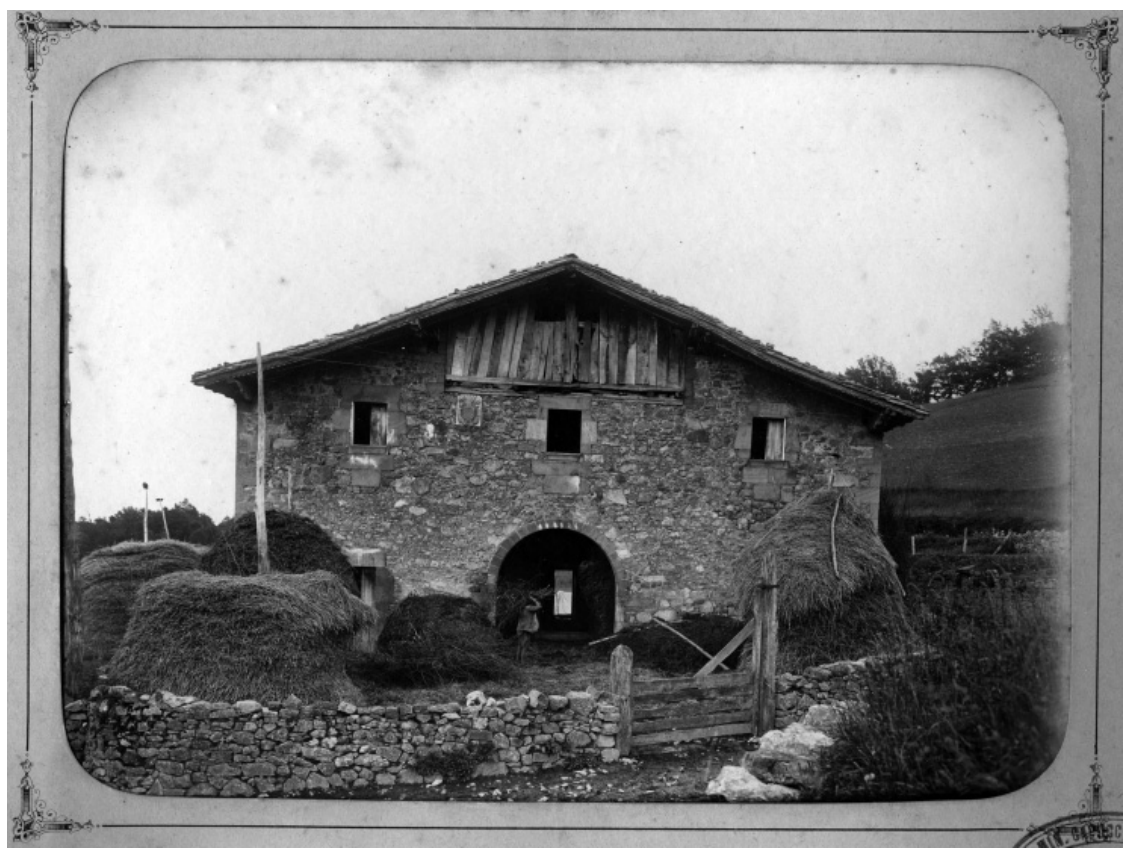

FIGURA 5.-Sagardibeltzea. Gartzain (Valle de Baztán).

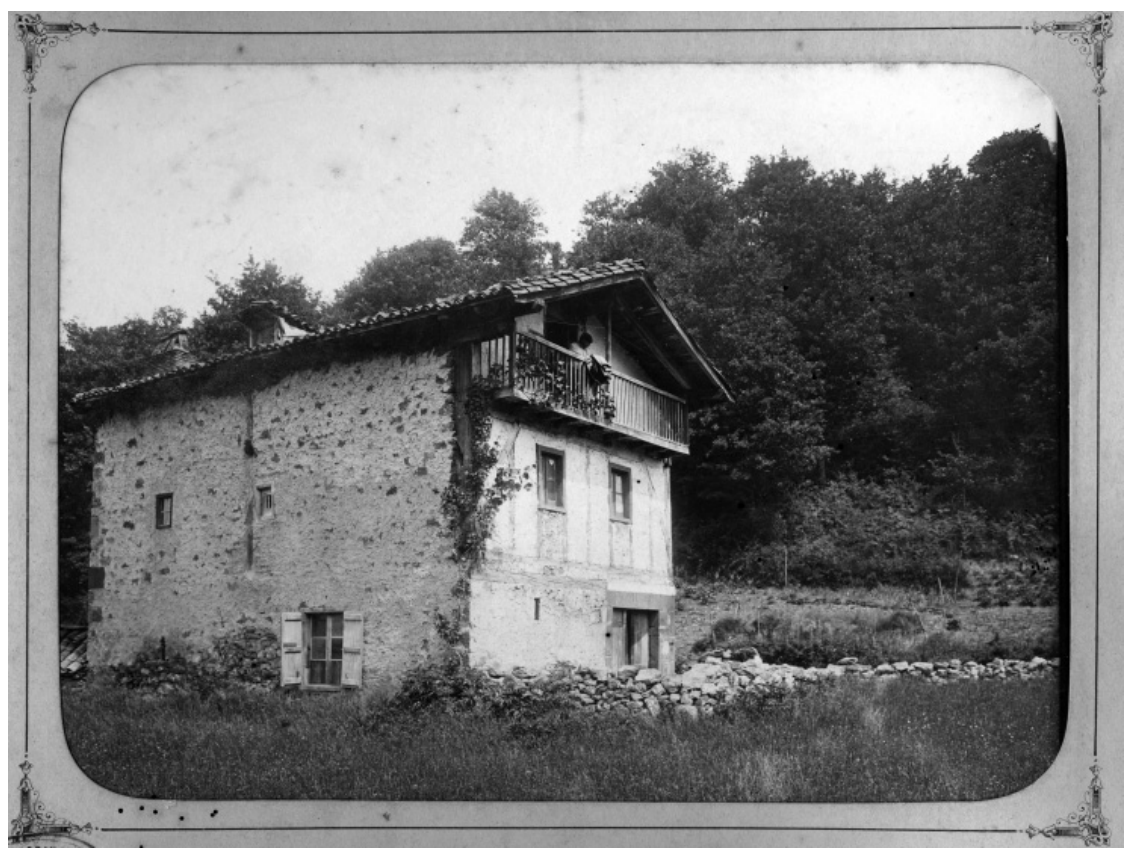

FiguRA 6.-Inda. Gartzain (Valle de Baztán).

Revista de Dialectología y Tradiciones Populares, vol. LXVIII, n. ${ }^{\circ}$ 2, pp. 385-422, julio-diciembre 2013, ISSN: 0034-7981, eISSN: 1988-8457, doi: 10.3989/rdtp.2013.02.016 


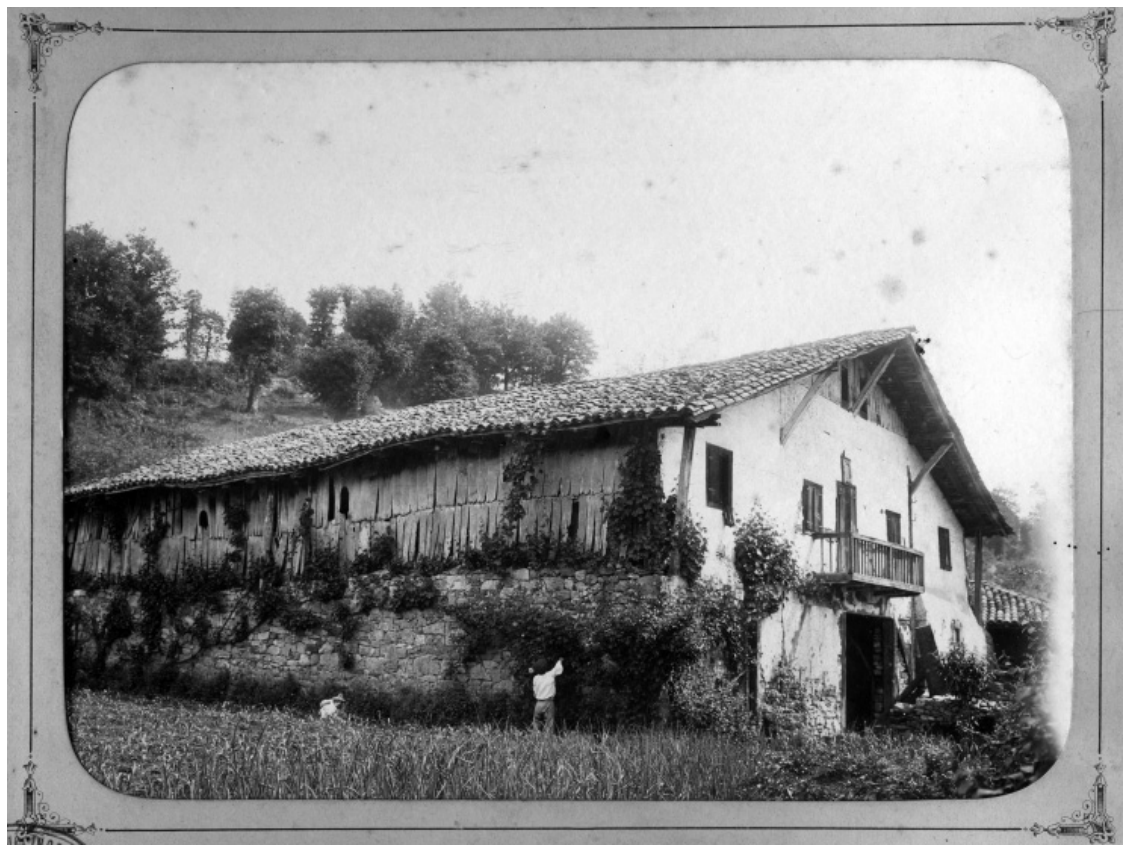

FIGURA 7.-Ugaldegaraia. Gartzain (Valle de Baztán).

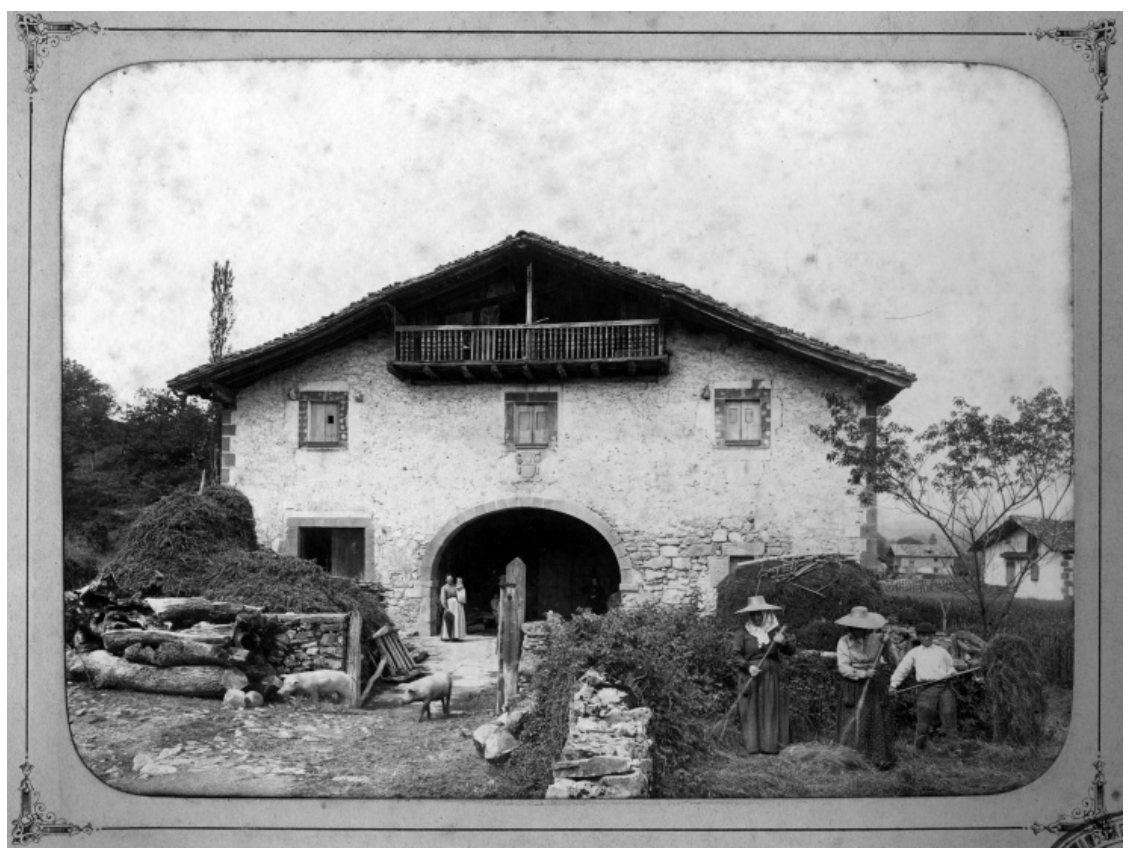

FiguRA 8.—Lapitzea. Gartzain (Valle de Baztán). 


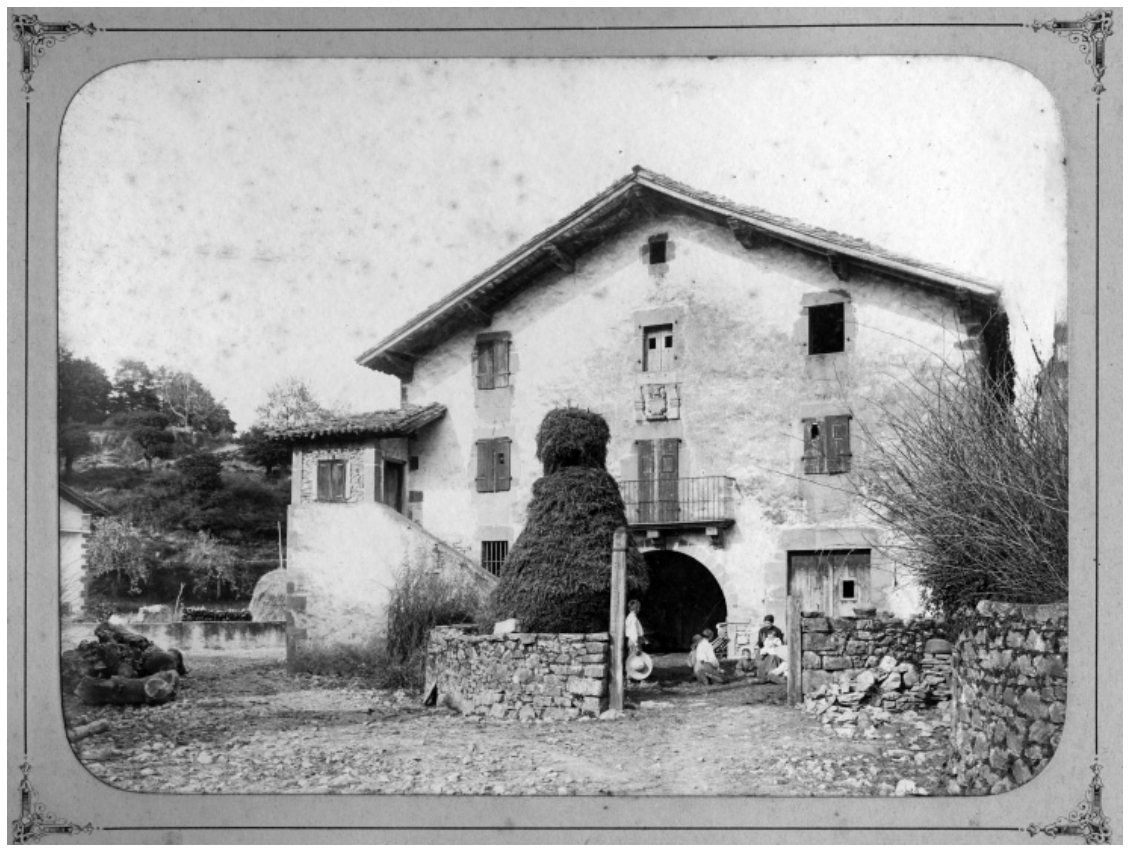

FIGURA 9.-Irunberea. Gartzain (Valle de Baztán).

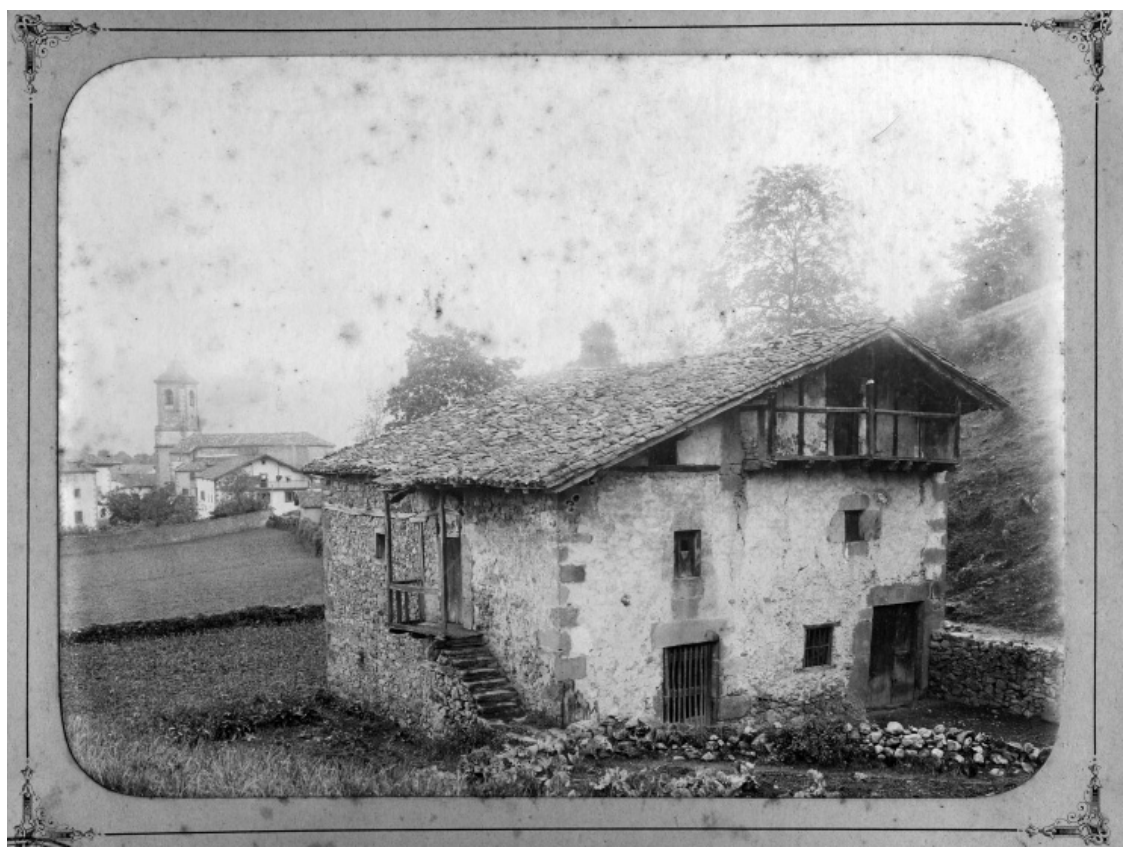

FiguRA 10._Erreka. Gartzain (Valle de Baztán). 


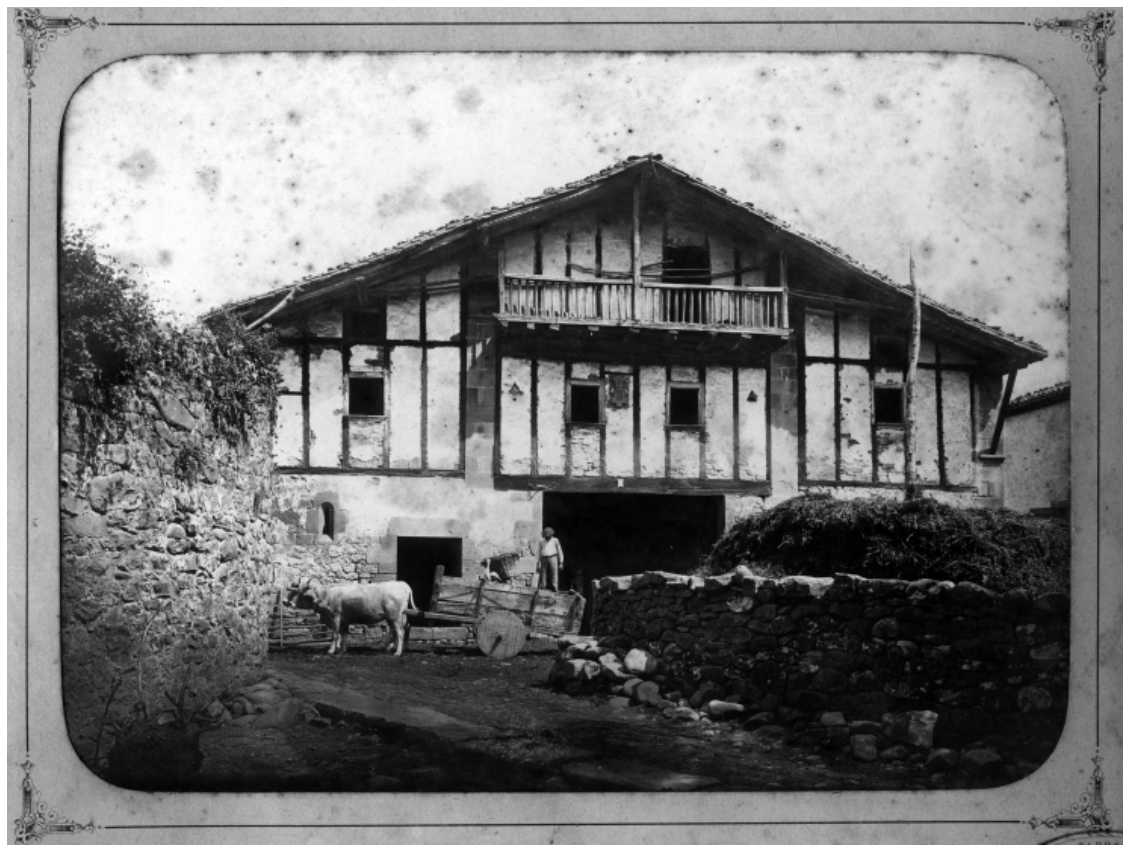

Figura 11.-Aldekoa. Lekaroz (Valle de Baztán).

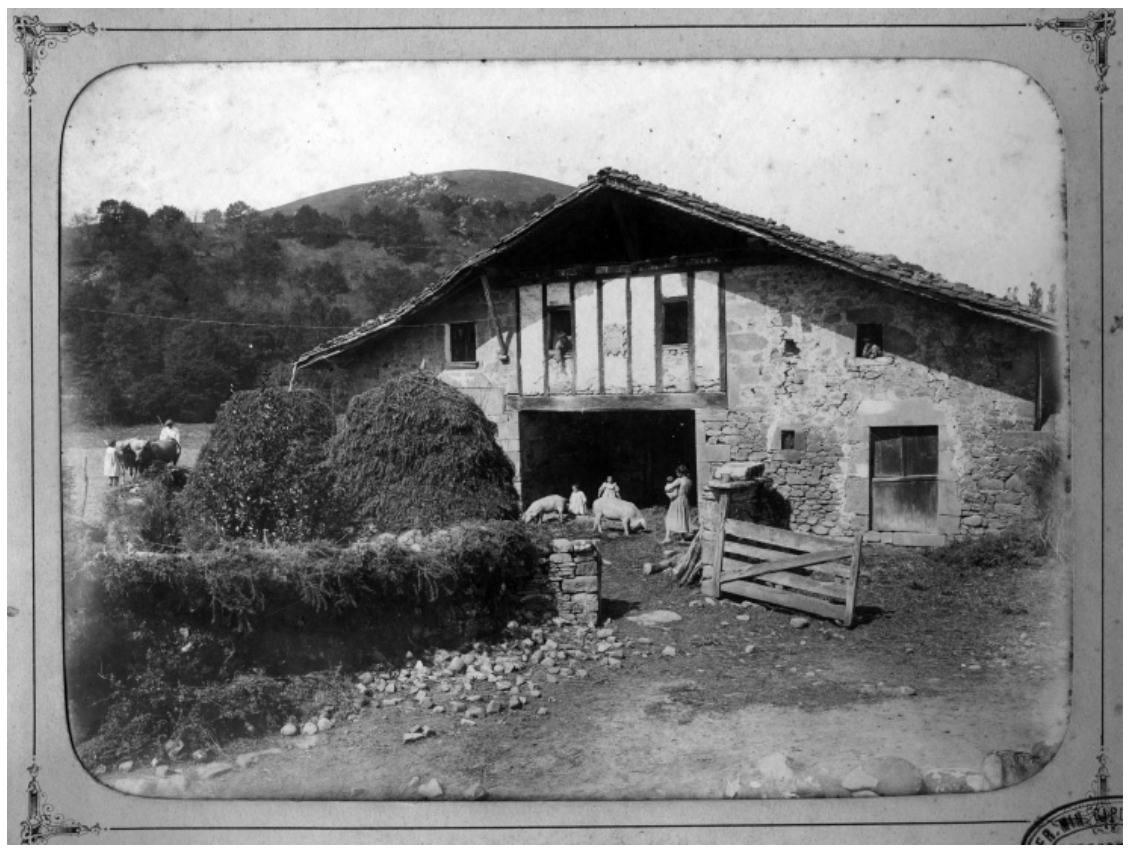

FiguRA 12.-Antxoneazarrea. Lekaroz (Valle de Baztán). 


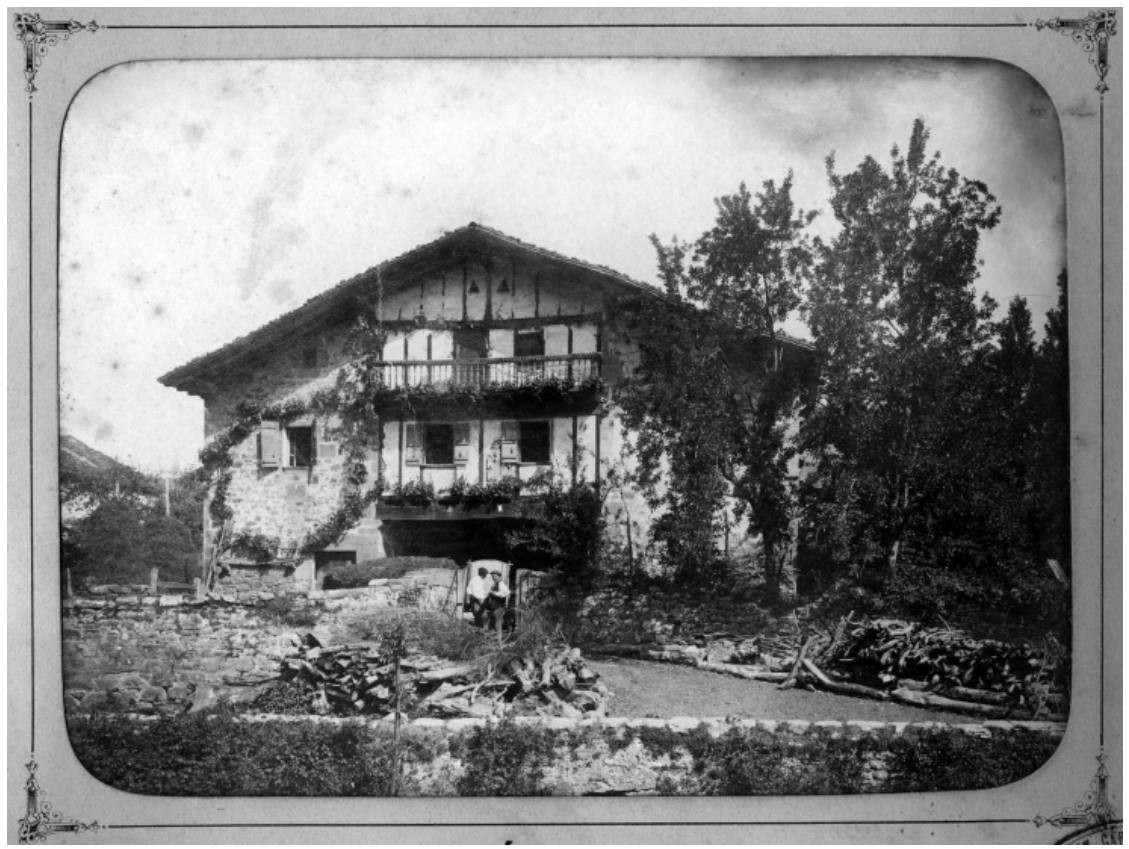

Figura 13.--Peruenea. Lekaroz (Valle de Baztán).

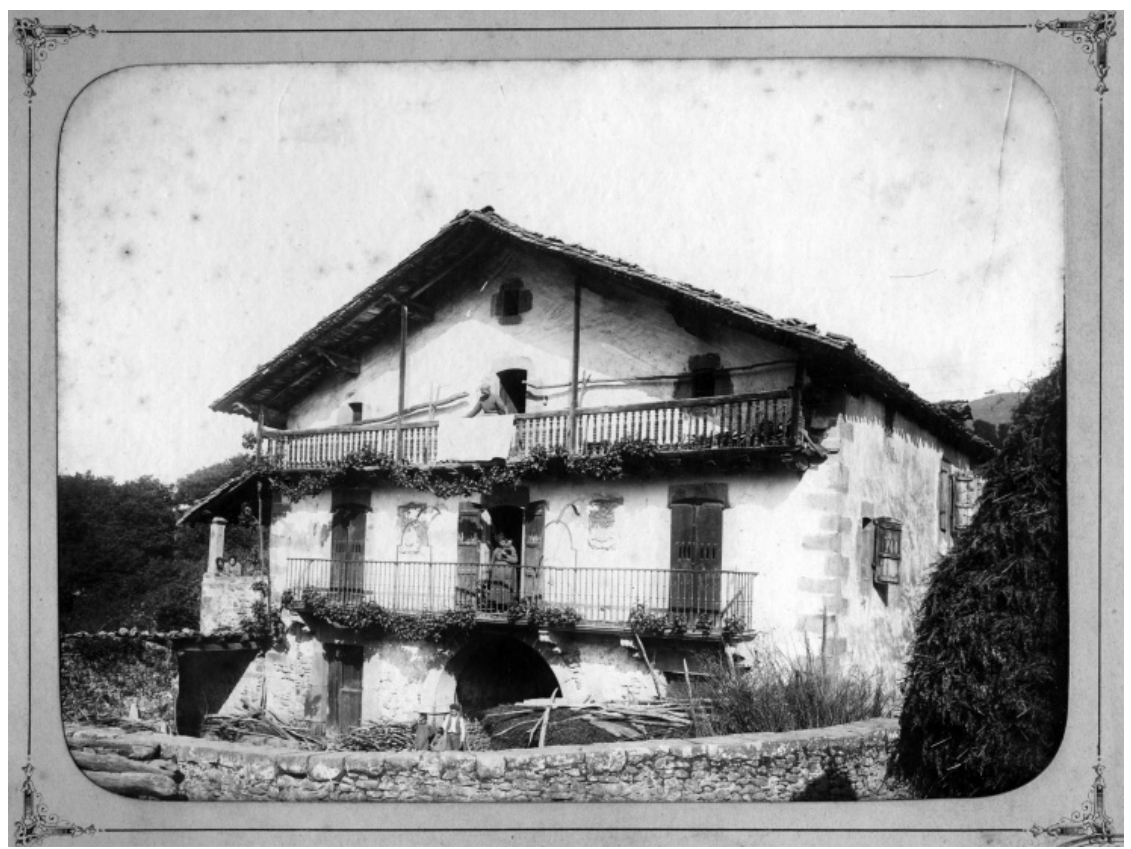

FiguRA 14.-Beitiko Xaarrea. Lekaroz (Valle de Baztán). 


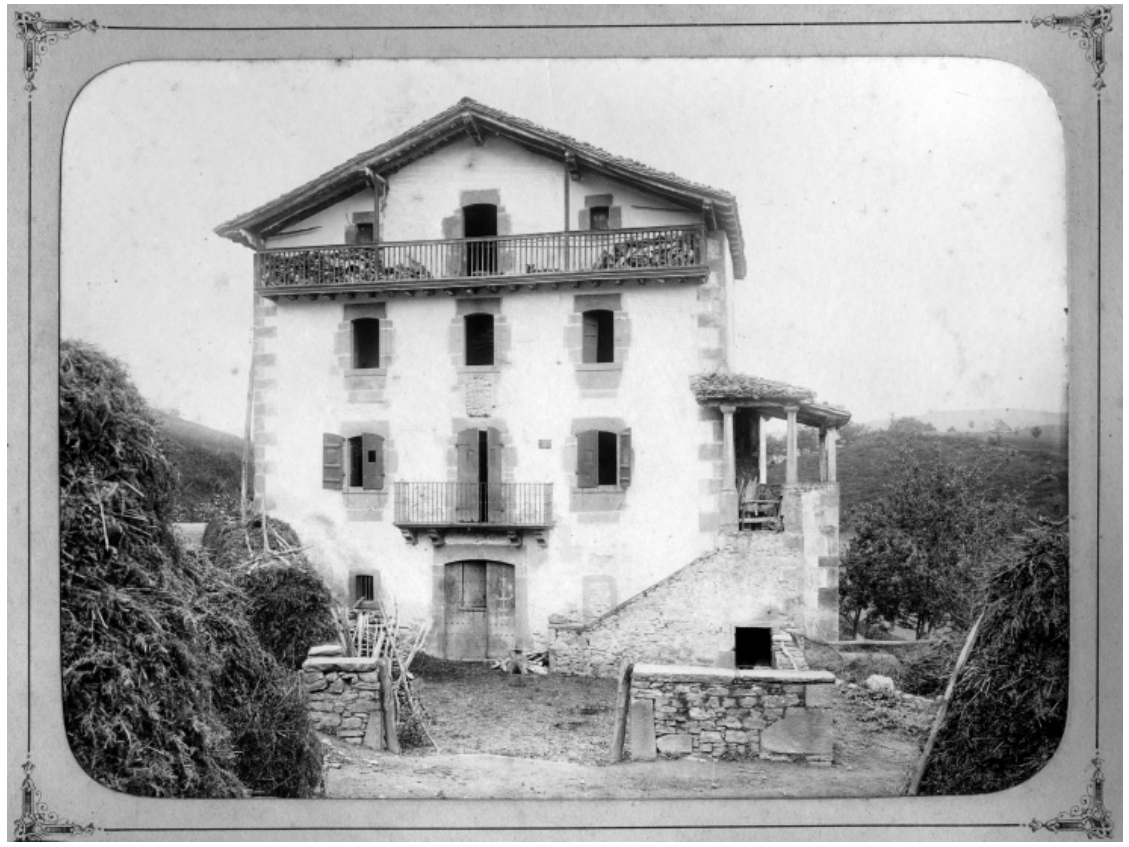

FiguRA 15.-Arginaga. Ziga (Valle de Baztán).

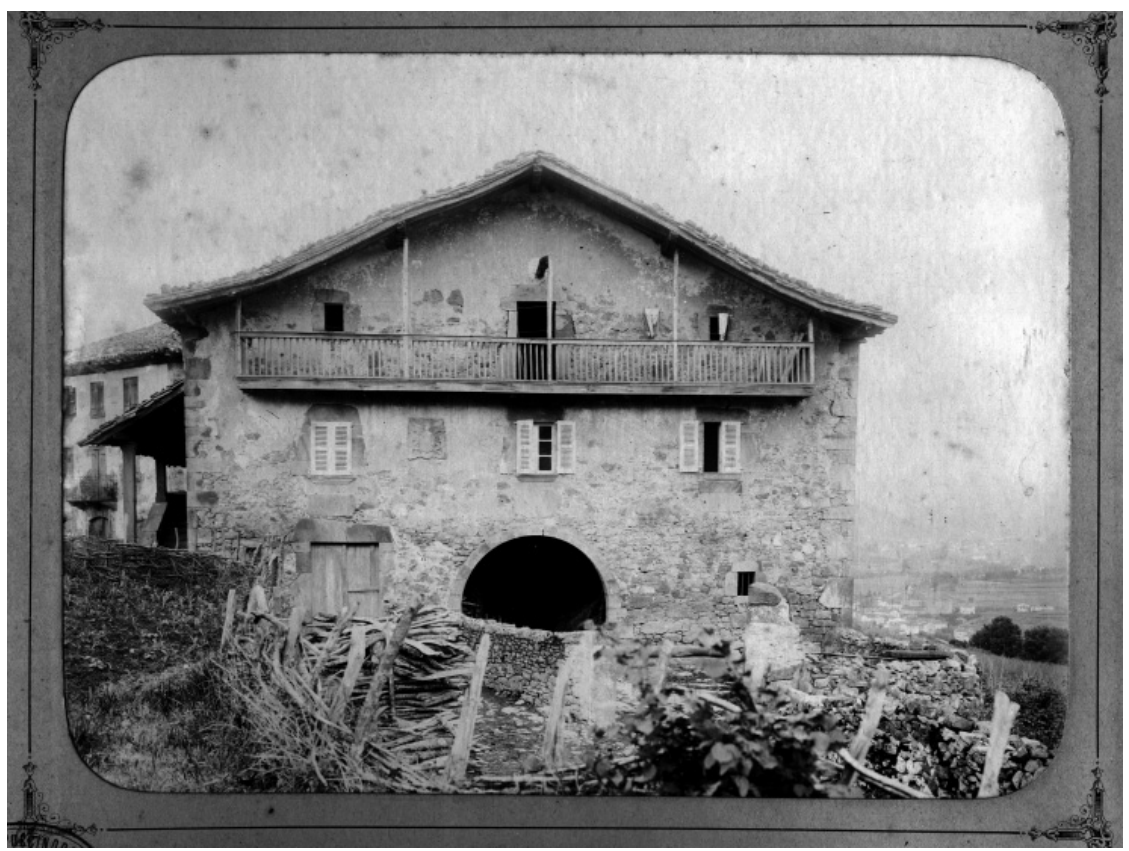

Figura 16.-Iturraldea. Ziga (Valle de Baztán). 


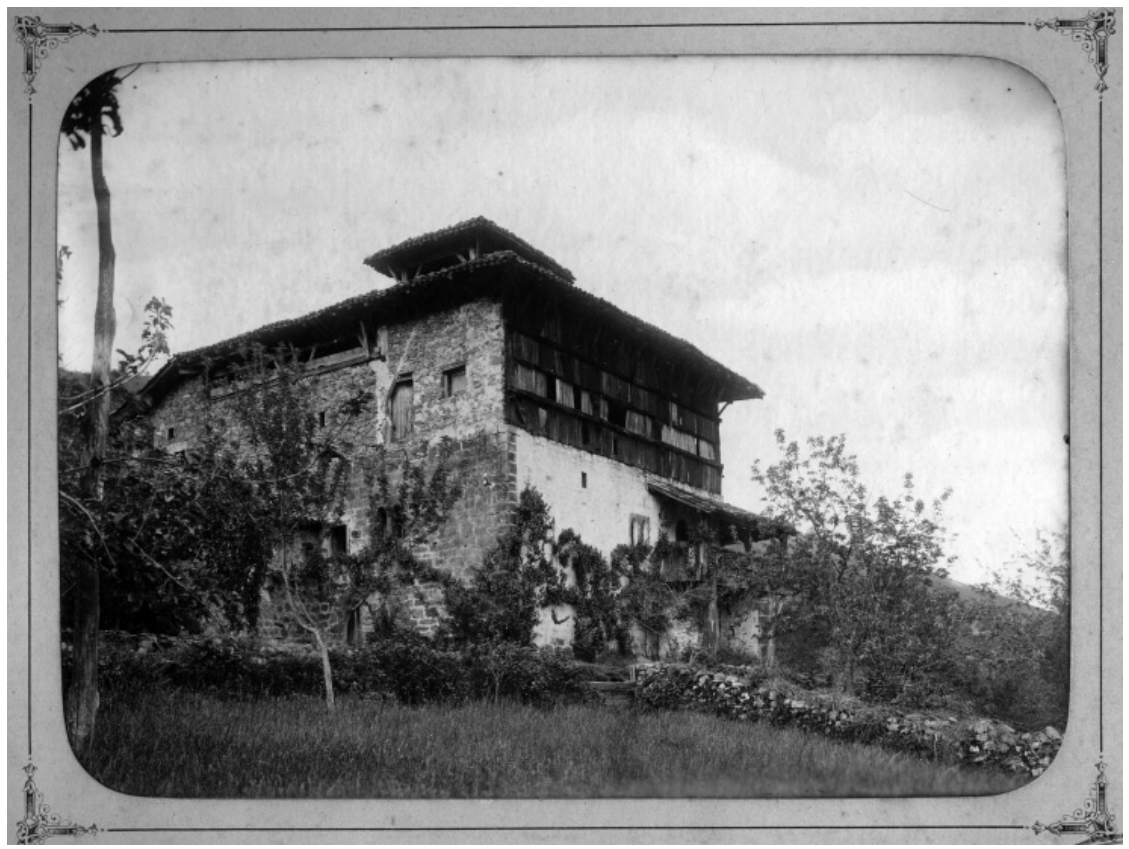

FIgURA 17.-Jauregizarrea. Arraioz (Valle de Baztán).

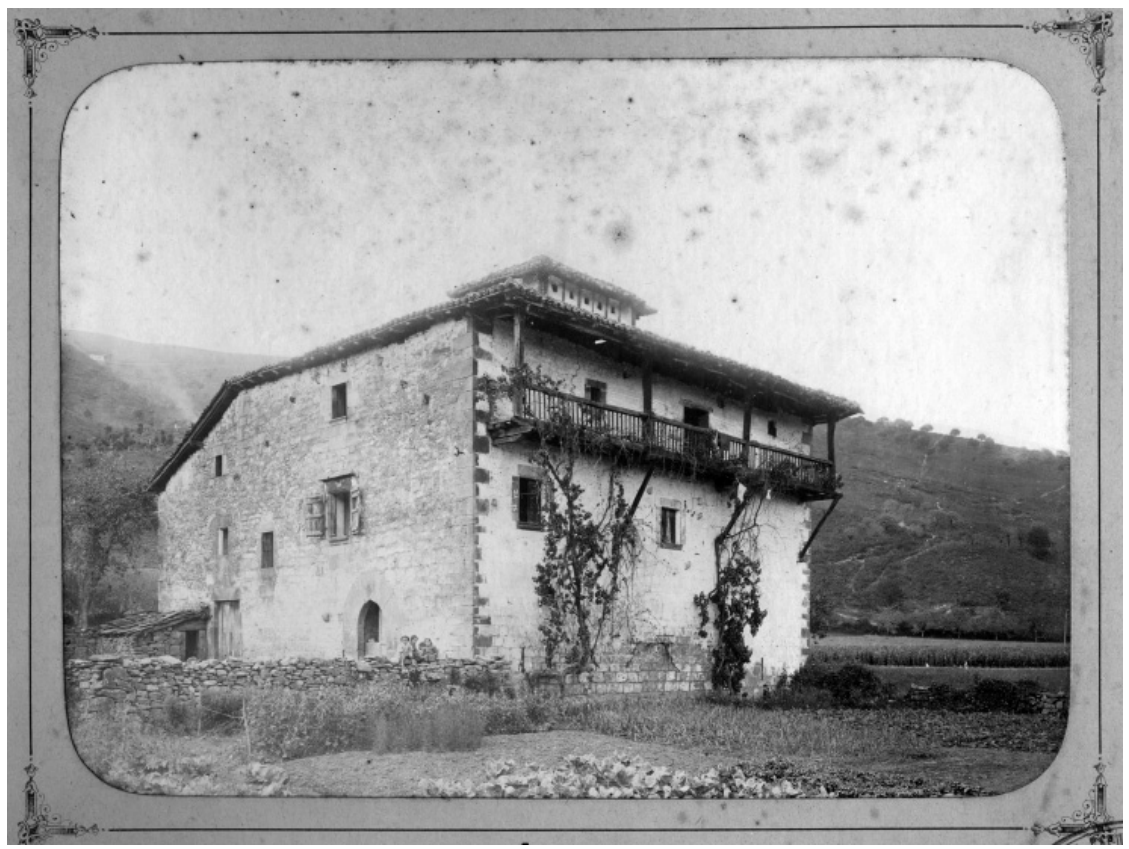

FiguRA 18.-Zubiria. Arraioz (Valle de Baztán). 


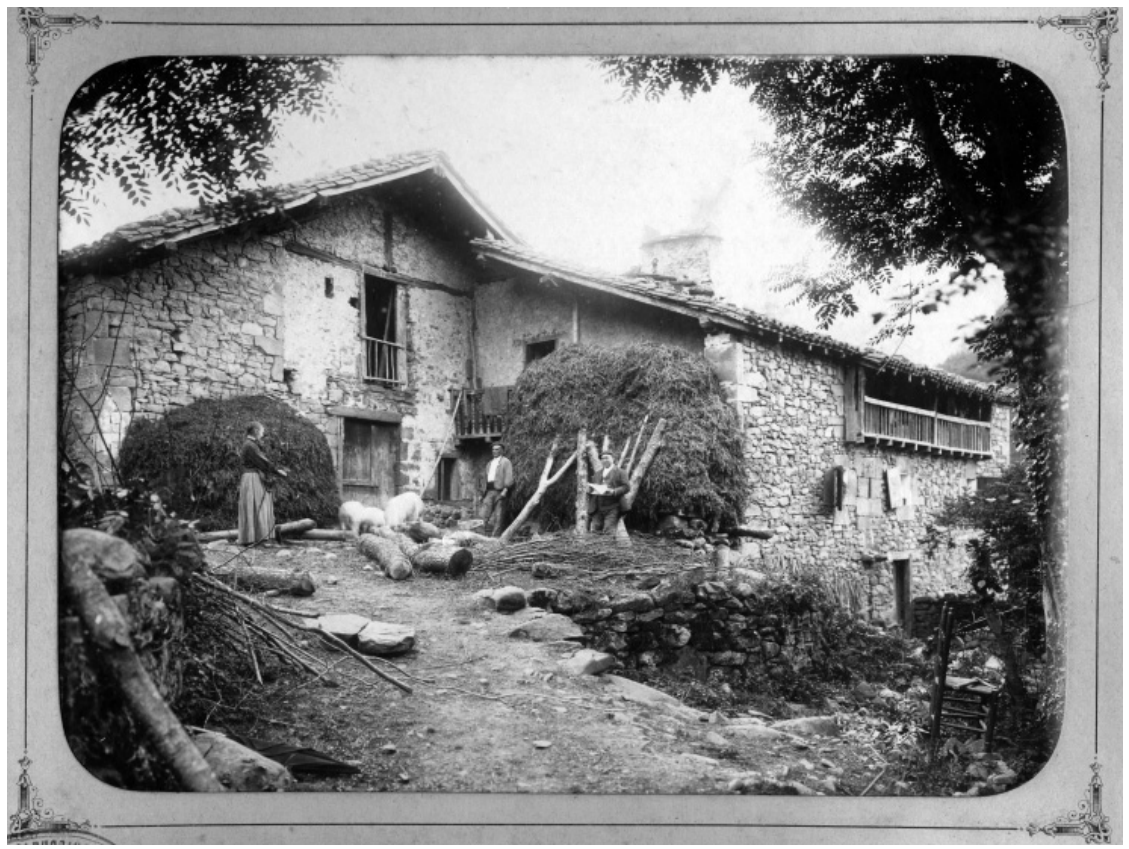

FIgura 19._Etxezuria. Amaiur (Valle de Baztán).

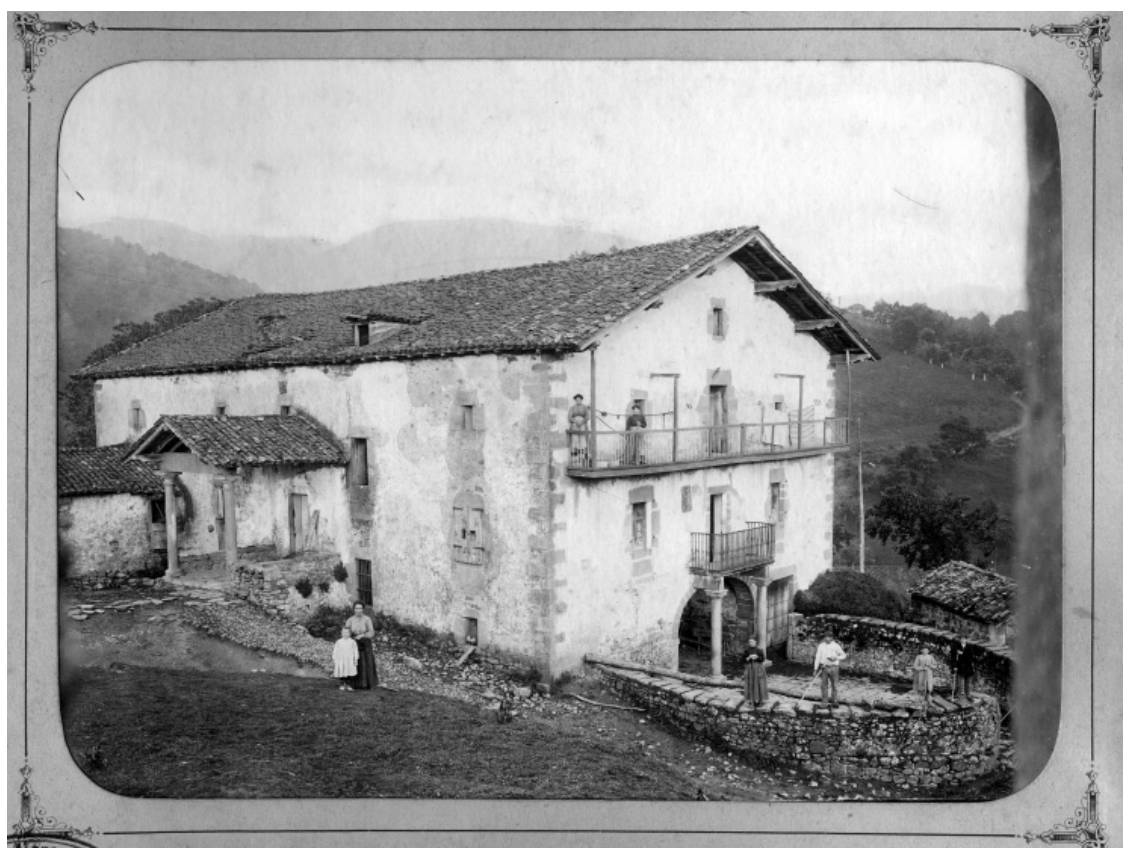

Figura 20._Zaldarriaga. Elizondo (Valle de Baztán). 


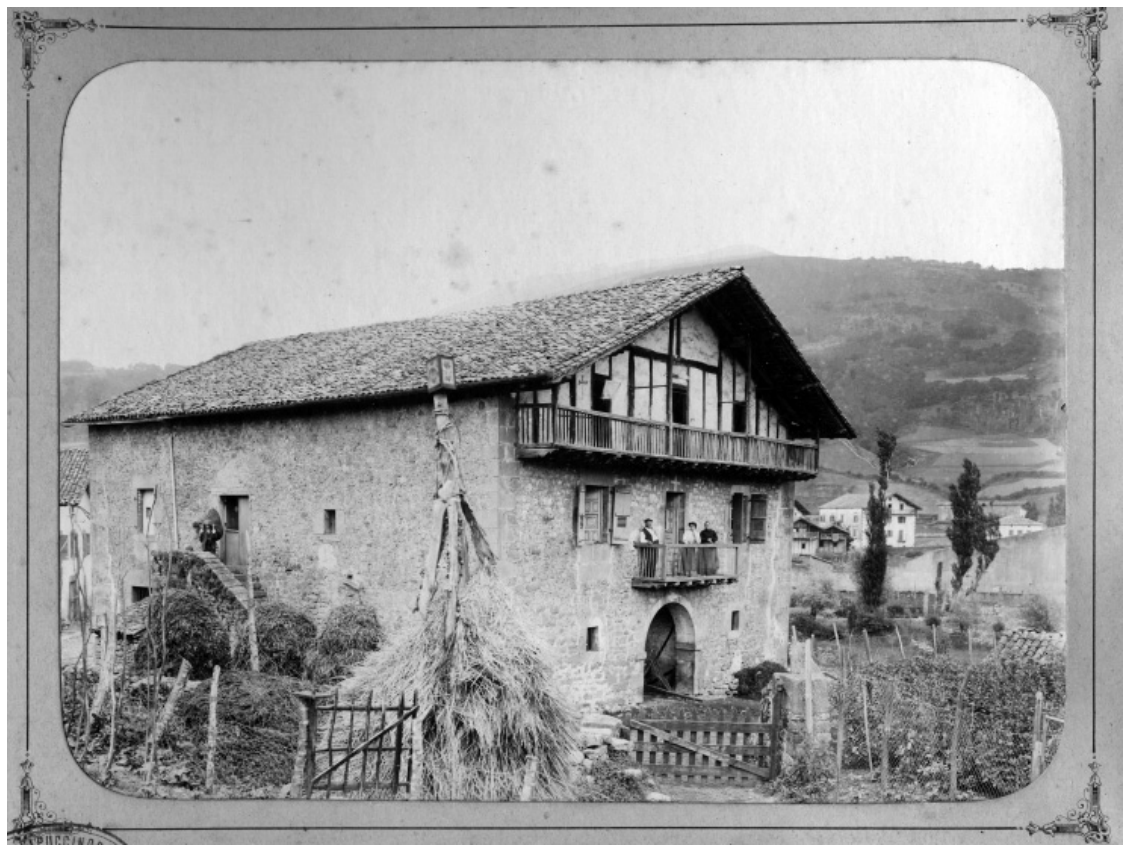

Figura 21.-Ugaldea. Erratzu (Valle de Baztán).

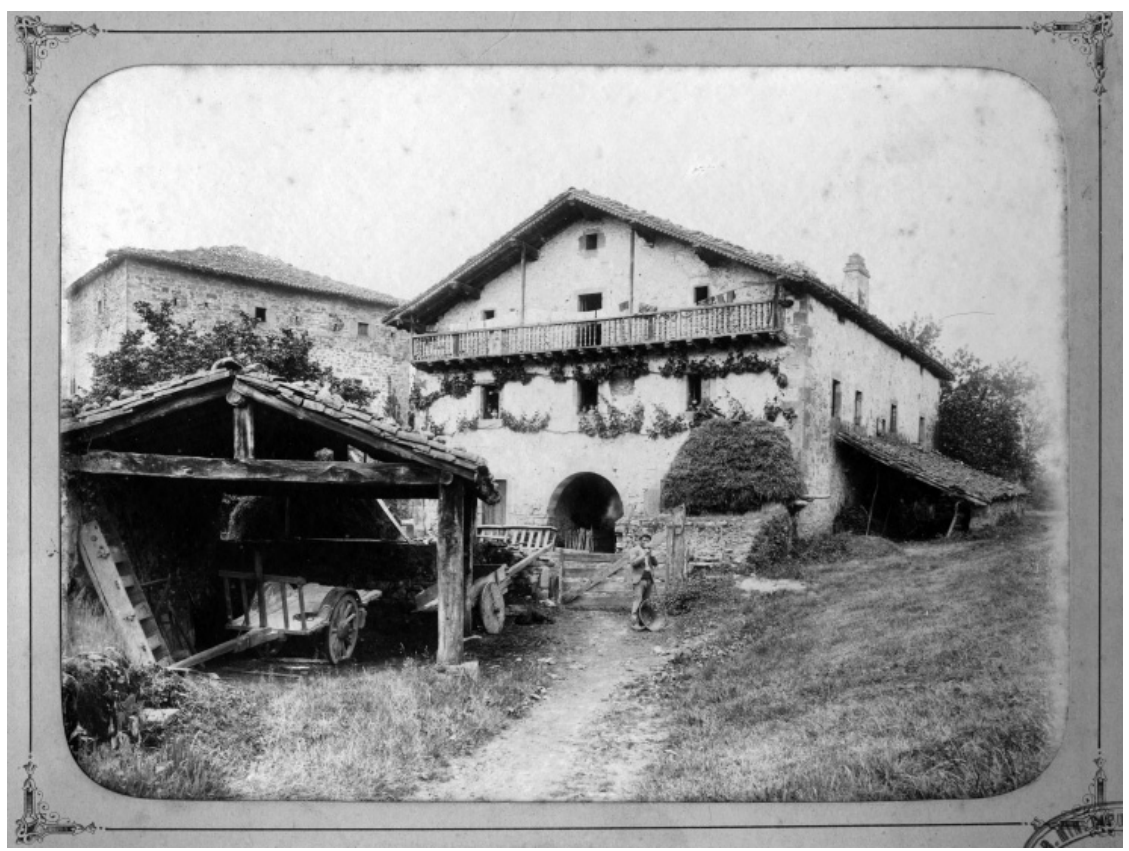

FiguRa 22.-Aldekoa de Jauregizar. Irurita (Valle de Baztán). 


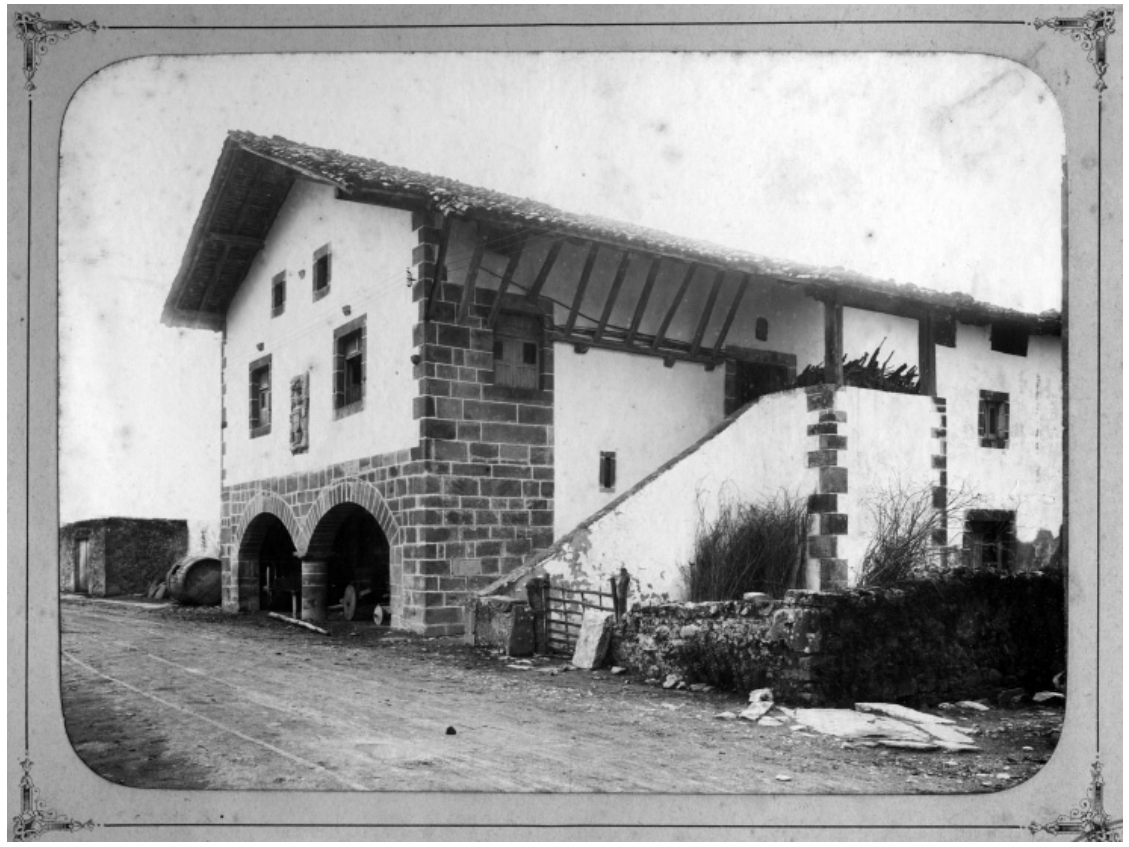

Figura 23.-Arretxea. Oronoz (Valle de Baztán).

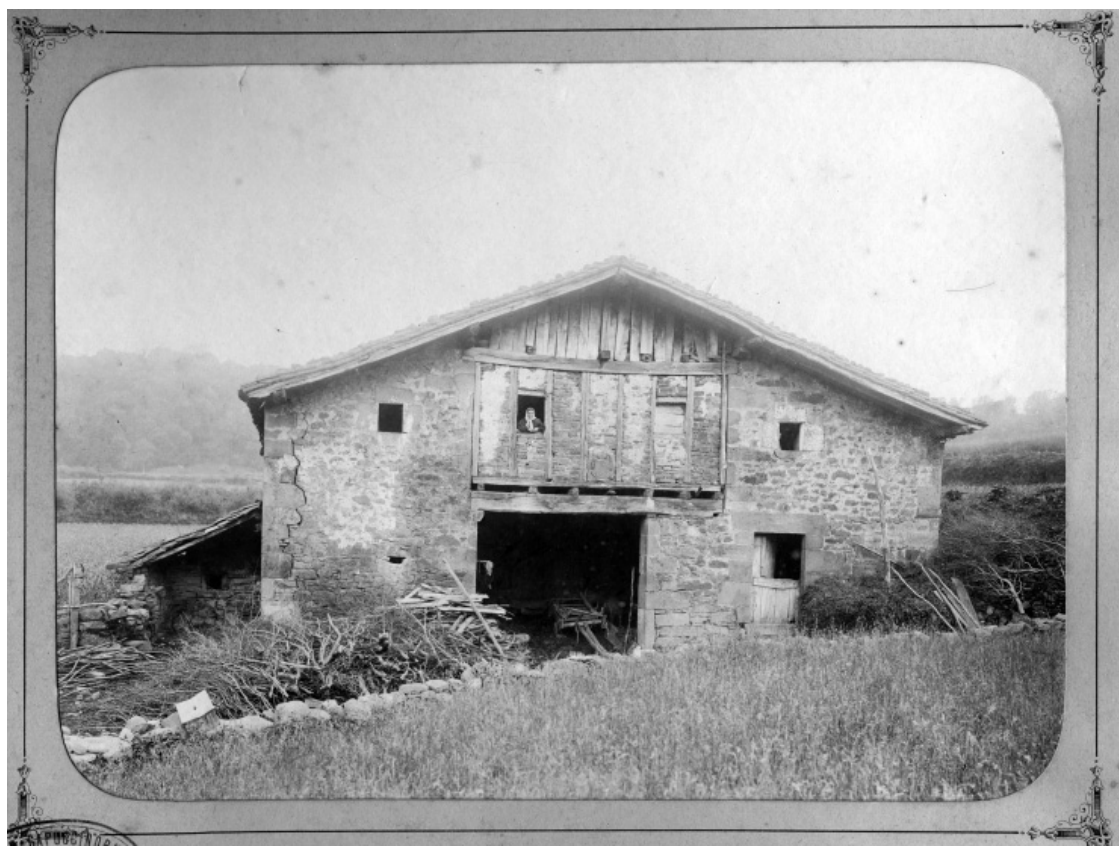

FIGURA 24.-Caserío sin identificar.

Revista de Dialectología y Tradiciones Populares, vol. LXVIII, n. ${ }^{2}$ 2, pp. 385-422, julio-diciembre 2013, ISSN: 0034-7981, eISSN: 1988-8457, doi: 10.3989/rdtp.2013.02.016 
El resto se encuentra distribuido entre otros núcleos de población baztaneses. Dos caseríos corresponden a Ziga o a su barrio de Zuraurre: Arginaga (donde trabajan los canteros o la casa del albañil, Fig. 15) e Iturraldea (casa de los Iturralde o bacia la fuente, Fig. 16). En Arraioz se levantan las dos monumentales casas-torre de Jauregizarrea (palacio viejo, Fig. 17) y Zubiria (junto al puente, Fig. 18). Finalmente, otras cinco localidades aparecen representadas con un único caserío: en Amaiur se encuentra Etxezuria (casa blanca, Fig. 19); en Elizondo, Zaldarriaga (pasarela de piedra, Fig. 20); en Erratzu, Ugaldea (casa de los Hualde o junto al río, Fig. 21); en Irurita, Aldekoa de Jauregizar (la de al lado del palacio viejo, Fig. 22); y a Oronoz corresponde la casa-palacio de Arretxea (casa de piedra, Fig. 23). No hemos llegado a identificar el que de forma errónea aparece como Zubiatea de Gartzain (Fig. 24).

El orden de colocación de las fotografías en el álbum no obedece al anterior criterio espacial, ni advertimos tampoco razones de tipo cronológico, toponímico o arquitectónico que lo justifiquen ${ }^{64}$. En la actualidad, se conservan al menos 19 de los 23 caseríos reproducidos por el capuchino; han desaparecido Inda y Ugaldegaraia de Gartzain, en tanto que Antxoneazarrea de Lekaroz se incendió en 1936, siendo sustituido por un edificio en su mismo emplazamiento, pero con diferentes características constructivas.

\section{VALOR DOCUMENTAL E IDEOLÓGICO DE ECHEZARRA: PAISAJE HUMANIZADO E IDEALIZACIÓN DE UN MODO DE VIDA}

El lema Echezarra (Casa vieja) ya da una idea del enfoque que Fr. Pedro de Madrid pretende plasmar en su colección fotográfica. Su intención es reflejar la forma de vida tradicional del agro baztanés, la institución social básica del valle: el caserío. Las imágenes que presenta son composiciones pictorialistas donde se conjugan en armonía el elemento arquitectónico —el caserío-, que domina la escena como símbolo de pervivencia, tradición y fortaleza, la heredad - propiedad y explotación agraria - y el factor humano - la familia - que vive, cuida y se nutre de él. Su discurso visual, en el que idealiza la vida rural y las relaciones sociales en torno al caserío y a la familia, se identifica plenamente con la esencia ideológica del certamen fotográfico pamplonés y, por ende, del catolicismo social representado en la VI Semana Social. Participa de esa visión arcádica de los valores encarnados por el campesino vas$\mathrm{co}$, alejada de la realidad pero tan arraigada en el pensamiento tradicional de la época ${ }^{65}$; valores de una sociedad rural que, si bien a principios del siglo XX todavía permanecían en valles aislados como Baztán, en numerosas zonas rurales de Guipúzcoa y

${ }^{64}$ El orden de colocación de los caseríos en el álbum es el siguiente: Aldekoa; Etxenikea; Andalorrea; Iturbidea (Norte); Antxoneazarrea; Arginaga; Sagardibeltzea; Inda; Peruenea; Ugaldegaraia; Aldekoa de Jauregizar; Etxezuria; Lapitzea; caserío sin identificar; Beitiko Xaarrea; Zaldarriaga; Jauregizarrea; Ugaldea; Arretxea; Iturraldea; Irunberea; Iturbidea (Sur); Zubiría; y Erreka.

${ }^{65}$ En sus Lecciones sobre la vida social en el País Vasco pronunciadas en la VI Semana Social de Pamplona, José de Posse identificaba tales valores con fe, amor a las libertades y tradiciones, organización familiar, respeto a la autoridad, y cariño hacia la tierra en que vive y explota como propia (Posse y Villelga 1916: 613). 
Vizcaya estaban desapareciendo a consecuencia de las profundas transformaciones sociales producidas por la industrialización y la concentración urbana.

No resulta casual en consecuencia que el artículo "El caserío vasco", firmado por J. M. de A., publicado en La Avalancha en 1913 e ilustrado con dos fotografías de Fr. Pedro, sea un canto al modo de vida idílico y autosuficiente del caserío ${ }^{66}$. En la misma línea, la revista Novedades insiste en la idea del caserío vasco como depositario de la noble vida patriarcal campesina y de la pureza de valores de familia y tradiciones, acompañando tales reflexiones con dos de sus fotografías firmadas en esta ocasión por Roldán ${ }^{67}$. Más explícito resulta si cabe el caso de La Esfera, en la que se reproducen a lo largo de 1920 varias fotografías de los caseríos obtenidas por el capuchino en 1912; de hecho, la colección baztanesa fue muy ponderada por los responsables de la revista al conectar con su línea editorial ${ }^{68}$, dado que encajaba perfectamente en la sección "Paisajes y Costumbres de España". El hecho de que sirviesen para ilustrar artículos referidos a diversas regiones españolas, ajenas por tanto a su origen, supone una prueba palpable de los valores ideológicos que transmiten: los de una sociedad rural tradicional en torno a la familia, enmarcada en un paisaje humanizado y armónico ${ }^{69}$. Para el tradicionalismo español, tales principios son extrapolables a cualquier ámbito, y por ello se aferrará a este tipo de imágenes como respuesta a la progresiva penetración en el medio rural de corrientes disgregadoras propias del librepensamiento, que atentaban contra las bases sociales establecidas.

Este principio rector resulta clave a la hora de abordar el valor documental e ideológico de las fotografías, imágenes de un paisaje humanizado en el que se hacen presentes la arquitectura del caserío y las actividades agropecuarias de la heredad, y

${ }^{66}$ "Adornamos el presente número de La Avalancha con dos fotografías de caseríos vascos de la colección de Fr. Pedro de Madrid que mereció ser premiada el año pasado. Acompañando a estas fotografías creemos verán con interés nuestros lectores la descripción de los cuatro elementos de que constan estos caseríos, que son: la casa, el ganado, la heredad y el monte... Criado el labrador vascongado en la vida sencilla, recogida y laboriosa del caserío, bajo la influencia de una autoridad paternal, robusta y patriarcal, mantiene costumbres dulces y puras, y no debe olvidarse que la educación de las familias es la base de la sociedad. Un buen sistema de laboriosidad y virtudes tradicionales han elevado este pueblo a un estado de prosperidad que envidian otras regiones más favorecidas por la naturaleza...". "El caserío vasco", La Avalancha, n 441, 238-1913: 190-191. Este artículo ya se había publicado en La Unión vasco-navarra (Bilbao, 1893) y reproducido en La Baskonia, nำ 702, 30-3-1913.

67 “Nada más típico, nada más representativo que el caserío vasco. En él se encierra y resume la noble vida patriarcal de nuestros campesinos, amantes como nadie de los puros goces del hogar, donde, con filial cariño, conservan, en toda su venerable pureza, las tradiciones de la raza. Si las razones apuntadas no fuesen bastantes, moveríamos a ilustrar nuestras páginas con las adjuntas fotografías, la singular belleza de éstas". "Páginas del país vasco", Novedades, 19-1-1913: 13.

${ }^{68}$ En el ideario editorial de la revista la fotografía llega a ser un documento en sí mismo, su valor testimonial la propia noticia, sin olvidar que a su vez es un trabajo creativo y artístico (Sánchez Vigil 1995: 205-258).

${ }^{69}$ La serie "Caseríos vascos" es lo más destacado de la colaboración de Satué en La Esfera. Al menos dieciséis fotografías suyas sobre este tema se publicaron en el segundo semestre de 1920, once de las cuales pertenecen a la colección premiada en el certamen pamplonés, cuyos pies de foto presentan localizaciones en los más diversos lugares de la geografía vasco-navarra. Las otras cinco son escenas de ambiente rural y costumbres populares que ilustran colaboraciones ajenas al origen navarro de las mismas; incluso una de ellas acompaña un artículo referido al campesino andaluz. "Retratos españoles. El hombre extático", La Esfera, nº 347, 28-8-1920: 28. 
testimonio de un modo de vida idealizado en torno a la familia como unidad socioeconómica en el mundo rural vasco-navarro.

Desde el punto de vista arquitectónico, el caserío, símbolo de lo inmanente, se erige en protagonista de la mayor parte de las fotografías, apreciándose en él las características que poco después iban a definir autores como Yrízar, Urabayen, Baeschlin o Aranzadi para esta tipología, la más genuina del País Vasco extendida igualmente a zonas geográficas de Navarra y del sur de Francia ${ }^{70}$.

Conviene a este respecto no perder de vista el momento histórico en el que surge la colección, coincidiendo con la aparición del regionalismo, corriente que busca sus fuentes de inspiración en las raíces propias de la región, de manera que el arquitecto vuelve la mirada hacia los estilos que se han desarrollado en ella a lo largo de los siglos para lograr a través de su análisis un orden arquitectónico regional (Navascués 1993: 675); pero no se trata de una simple copia, sino de la adaptación de un determinado lenguaje local a las necesidades modernas (Clozier 1936; Vigato 1994).

Pues bien, la arquitectura del País Vasco interpreta el regionalismo en clave de aceptación y vigencia de los modelos vernáculos, con una marcada ascendencia popular basada en el caserío, construcción que conservaba su primitiva pureza y en la que había que buscar el espíritu regional, y no en la ciudad que lo desvirtuaba y homogeneizaba. Sobre este tema —al que no resultan ajenos en algún caso ciertos ecos nacionalistas - reflexionaban arquitectos como Pedro Guimón, quien proponía la arquitectura del caserío vasco como modelo a seguir, por cuanto, además de ser el ejemplo más representativo del arte popular, se erigía en "distintivo de patria y nacionalidad" (Guimón 1907: 33-64; Guimón 1919: 120-124; y Guimón 1924: 9-16). En 1916, Leonardo Rucabado reconocía que el País Vasco fue capaz de ver en las "viejas prácticas" de los caseríos las formas "para las elegantes residencias urbanas y campestres" (Rucabado 1916: 1-8). Y en parecidos términos se expresaba Pedro Muguruza pocos años más tarde (Muguruza 1918: 199-202; y Muguruza 1919: 244-248). Incluso un personaje ya familiar, José de Posse, escribía en 1914 una serie de artículos sobre el caserío vasco en la revista Euskalerriaren alde, aseverando que la ciudad era el "mal del siglo" ante el que sucumbía el modo de vida tradicional vasco, identificado desde antiguo con la montaña y el caserío ${ }^{71}$.

El caserío se erige, así, en símbolo de identidad y afirmación del territorio y, en consecuencia, en modelo a seguir por la arquitectura regionalista vasca del primer tercio del siglo XX. Éste es, a grandes rasgos, el marco en el que se inscribe la colección fotográfica de Fr. Pedro de Madrid premiada en el certamen pamplonés. No quiere ello decir que nuestro capuchino participara necesariamente de los valores aquí reseñados; pero sí que sus fotografías sirvieron más de una vez como apoyo gráfico de tales teorías. Uno de los ejemplos más significativos proviene nuevamente de $L a$ Esfera, que en 1920 publicaba un artículo firmado por Martín Ávila (seudónimo del periodista Dionisio Pérez), en el que se preguntaba de forma retórica si existía una

\footnotetext{
${ }^{70}$ Yrízar (1929); Urabayen (1929); Baeschlin (1930); Aranzadi (1932). Posteriormente Madariaga (1980); Caro Baroja (1982); García Gainza y otros (1994); Ávila Ojer y López Echarte (1996: 3348); Igoa Moreno (2008); y Atlas Etnográfico de Vasconia 1-2 (2011).

71 Hasta un total de nueve artículos de José de Posse aparecen publicados en 1914 en Euskalerriaren alde. Revista de cultura vasca, con el título genérico de "El Caserío. Medios de aumentar sus rendimientos" (Véase Martínez Gorriarán y Agirre Arriaga 1995).
} 
"arquitectura vasca" en una época en la que San Sebastián y Bilbao estaban "europeizándose" arquitectónica y urbanísticamente; la respuesta era afirmativa, como quedaba de manifiesto en las nueve fotografías de caseríos vascos obtenidas en 1912 (en el artículo aparecen como "Fots. Satué") que ilustraban el texto y que marcaban a su entender la pauta a seguir por el regionalismo vasco $^{72}$.

Los caseríos fotografiados por Fr. Pedro de Madrid se ajustan a las características propias de esta tipología: planta regular y maciza con predominio de la longitudinalidad; aparejo mixto con presencia del sillar en esquinales y recercos de los huecos; fachada principal en la que se suceden un nivel inferior, una o dos alturas con ventanas y balcones regularmente colocados, y desván, con cubierta a doble vertiente que termina en un alero volado de madera; y sobriedad ornamental, limitándose el adorno exterior de la casa a la labra y talla de ménsulas, balcones y aleros, la ornamentación polícroma mediante motivos pintados (en algún caso en forma de cruces, de manera que a la función decorativa se suma la religiosa) y, por encima de los demás, el escudo o piedra armera, elemento por excelencia que decora - a la vez que ennoblece- el caserío baztanés, en el que se repite de forma invariable el ajedrezado o escaqueado, blasón colectivo del Valle y Universidad de Baztán (Pérez de Villarreal 1988: 179-233).

Así definidos sus rasgos generales, podemos significar no obstante algunos elementos particulares, como la doble variante de fachada, bien con entramado de madera y acceso al gorape bajo una gruesa viga adintelada de roble, bien con ausencia de entramado e ingreso a través de un arco de medio punto o abocinado; la presencia en Ugaldegaraia de Gartzain de un cerramiento lateral de madera, pretendido rasgo de antigüedad en la construcción que enlaza con un pasado en el que los edificios eran íntegramente de este material; el carácter asimétrico de algunas cubiertas como consecuencia de un agregado posterior (Etxenikea y Erreka de Gartzain); y la presencia de otros elementos arquitectónicos, caso del patín o escalera exterior que permite acceder a la primera planta (Baeschlin 1930: 134-135; Amesti Mendizábal 1997: 55-106), y de pequeños cobertizos para guardar la leña y los aperos de labor, o con otras funciones como horno de pan (caserío sin identificar) o cobijo del pozo de agua (Andalorrea de Gartzain).

Signifiquemos para concluir este apartado arquitectónico que, si bien el caserío vasco es el tipo dominante, Fr. Pedro de Madrid quiso dejar constancia de otras construcciones también representativas de la zona. Así ocurre con Jauregizarrea y Zubiria de Arraioz, que obedecen a una tipología común de casa-torre medieval, levantadas en los siglos XIV-XV con finalidad defensiva (Martinena Ruiz 1997 y 2008). Por su parte, Arretxea de Oronoz, construcción del siglo XVI que alcanzó el título de palacio cabo de armería una centuria después, se convierte en prototipo de edificio intermedio entre la vivienda rural y la urbana, por cuanto, si bien conserva la silueta característica del caserío de labranza, está construida con materiales y elementos dignos de una residencia señorial (Baeschlin 1930: 36-37).

\footnotetext{
72 "Hay una arquitectura vasca. Son caseríos de campesinos, pero fueron antaño palacios de nobles e hidalgos. Su austeridad, su sencillez, su ponderación entre la utilidad y la belleza postergando ésta, son un reflejo exacto del espíritu vasco... En los ruinosos ejemplares que quedan, los artistas podrán encontrar suficientes elementos constructivos y decorativos para resucitar la arquitectura vasca, para crear la casa nueva que conserve la tradición regional. Ávila, M., "Resurrección regional. Las moradas de Vasconia", La Esfera, no 343, 31-7-1920: 20-21.
} 
Con todo, en sus fotografías de caseríos baztaneses, el capuchino no se limitó a la arquitectura, sino que, como documento gráfico de un modo de vida, contextualizó las viviendas rurales en su medio natural, vinculadas al paisaje y heredad en el que se levantan, a la familia que los habita y a las labores que se desarrollan en su entorno. En efecto, el caserío organiza no sólo el espacio, sino también la población, por cuanto cada familia está adscrita a una casa y a un lugar geográfico determinado del territorio ${ }^{73}$.

El escenario de los caseríos nos habla de paisaje y heredad. El paisaje muestra los prados y laderas vecinos donde crecen los pastos para el ganado, completándose con los bosques y montes de las inmediaciones de los que se extraen el helecho y la leña. Al concepto de paisaje se vincula el de heredad o zona cultivada, por cuanto el baserritarra tiene siempre, unidas o próximas al caserío que habita, las tierras que cultiva para la subsistencia familiar y de los animales ${ }^{74}$. Forman parte de la heredad los cultivos de hierba o de maíz situados en las inmediaciones del caserío, las pequeñas huertas (Ugaldea de Erratzu) y las conocidas metas, sistema tradicional de almacenar el heno, paja o hierba que actúa como pajar al descubierto; puntualmente aparecen en el belardi o prado inmediato al caserío (Peruenea y Beitiko Xaarrea de Lekaroz), pero la mayoría se levanta junto a éste, ubicación que, además de protegerlas de las inclemencias meteorológicas, proporciona mayor comodidad, por lo que superan en tamaño y altura a las de los prados (Almandoz 1997: 269-288).

Arquitectura y paisaje se encuentran humanizados, es decir, ligados a quienes habitan el caserío y cultivan sus tierras. Recordemos a este respecto que el caserío no se define únicamente por ser un edificio o una unidad de producción agraria, sino que constituye una célula familiar y social; buena prueba de ello es que con frecuencia a sus habitantes se les conocía - y todavía se les conoce- por el nombre de éste, más que por su propio apellido. De ahí la trascendencia que adquiere en el ámbito social, simbólico e incluso ideológico en buena parte del territorio vasco-navarro.

La propiedad del caserío y sus terrenos se transmitían íntegros en el seno de la misma familia. La solución adoptada desde principios del siglo XVI hasta finales del XIX fue la de donar el caserío al hijo/a designado en el mismo momento en que contraía matrimonio. Esta práctica permitió que la superficie de las explotaciones no se fragmentase para garantizar la supervivencia de los labradores, pero no impidió que se formasen grupos sociales definidos por su diferente posición respecto a la propiedad de la tierra (Caro Baroja 1976: 126-130; Santana y Otero 1993: 76). La clase privilegiada la integraban los dueños de varios caseríos, propietarios por transmisión familiar, rentistas que ya nada les vincula con el lugar. Más numerosos son los pequeños propietarios, las familias que se dedicaban a explotar directamente los re-

\footnotetext{
${ }^{73}$ Son numerosos los estudios que abordan la realidad y evolución socioeconómica del caserío vasco. Citemos los de Martín Galindo (1969); Etxezarreta (1977); Goikoetxea López (1991: 101123); Martínez y Mauleón Gómez (1994: 275-282); Mauleón (1998); y Alberdi Collantes (2001: 135150; 2002: 5-17 у 2009: 395-404).

${ }^{74}$ Aunque todos los caseríos son explotaciones agrarias minifundistas, existen notables diferencias en cuanto a la superficie y capacidad de la heredad; los más pequeños no sobrepasan las dos hectáreas, si bien hay caseríos con ocho y diez. Un cálculo medio sitúa la heredad del caserío tradicional en cuatro hectáreas y apenas alcanza las diez de extensión si incluimos la superficie forestal (Cruz Mundet 1997: 13-39; Ruiz Urrestarazu y Galdos Urrutia 2005: 79-91).
} 
cursos de su casa solar heredada; es de suponer que la mayoría de los caseríos de la colección fotográfica pertenece a esta categoría. Finalmente, el grupo de los arrendatarios o maisterrak era también considerable, e incluso en algunos casos la misma familia permanecía en el caserío por generaciones; con toda seguridad en la colección aparecen familias de arrendatarios, habitantes de los edificios más humildes.

La composición familiar del caserío está muy relacionada con el sistema de heredero único. Por lo general, las familias propietarias forman hogares con más miembros que los de una familia simple compuesta por padres e hijos. Caro Baroja (1976: 124-125) nos presenta como prototipo una familia compleja integrada por un matrimonio de edad madura (los padres, antiguos propietarios), un matrimonio más joven (los actuales propietarios), los hijos de estos (jóvenes y niños) y algún pariente cercano (normalmente, hijos/as del primer matrimonio, o tíos/as del matrimonio propietario) (Arizcun Cela 1988: 60).

Conocedor sin duda de todos estos valores, Fr. Pedro de Madrid incluye el elemento humano en la mayor parte de las fotografías de los caseríos baztaneses. Además de sus cualidades técnicas, es destacable igualmente la capacidad que como director de escena demostró en todo el trabajo: la composición es fruto de los requerimientos del capuchino para que sus moradores aparezcan en un lugar concreto de la imagen; y no sólo eso, sino actuando en consonancia con el papel asignado a cada uno de ellos en la vida cotidiana del caserío. El valor documental que estas escenas añaden a la serie es, en este sentido, notable ${ }^{75}$.

El número de habitantes del caserío ofrece un amplio abanico de posibilidades. En algunas fotografías es evidente que son familias extensas, formadas por diversas generaciones y familiares cercanos (Lapitzea de Gartzain, Zaldarriaga de Elizondo, Ugaldea de Erratzu). Por el contrario, los caseríos más dispersos parecen estar habitados por familias nucleares, probablemente arrendatarios (Inda de Gartzain). Tanto el emplazamiento que ocupan como la actitud que muestran, obedecen a diversas variantes: delante de la fachada principal o asomados a sus huecos y tribunas, desarrollando con total naturalidad sus tareas cotidianas o posando para el fotógrafo de manera consciente. Mas con independencia de todo ello, la sensación que transmiten es de serenidad y dignidad en medio del trabajo, una imagen idealizada que se aleja de las verdaderas y duras condiciones de vida en el caserío $^{76}$.

La indumentaria revela igualmente aspectos de interés (Albisu Iriarte 2006). Los hombres aparecen ataviados con camisa de lino blanco y pantalón oscuro que ciñen en ocasiones con la típica faja recogida a la cintura; la mayoría cubre su cabeza con una boina corta. Calzan alpargatas y, para protegerse del barro usan los eskalapuñek, zuecos de madera claveteados (Aldekoa de Jauregizar en Irurita, Zaldarriaga de Elizondo). En la indumentaria femenina, es característica la camisa o blusa, y la saya o falda larga que llega hasta los tobillos; prenda generalizada es el mandil o delantal. Por su parte, los niños visten blusones y pantalones debajo de estos, en tanto que las niñas llevan vestidos.

\footnotetext{
75 A propósito de la fotografía como memoria familiar, resultan de sumo interés los trabajos de Ortiz García (2005 y 2006); Sánchez Montalbán (2006) y Grilli (2006).

${ }^{76}$ Son de interés las reflexiones que realizan a este respecto Ruiz Urrestarazu y Galdos Urrutia (2005: 79-91).
} 
Abordemos finalmente las faenas agrícolas ${ }^{77}$. A la vez que definen un determinado modelo arquitectónico, social y familiar, las fotografías de Fr. Pedro de Madrid plasman gran parte de las actividades que configuran la economía tradicional del caserío baztanés; es más, nos atrevemos a asegurar que calculó minuciosamente cada una de las imágenes, con sus trabajos y actores, para componer un verdadero mosaico de la vida cotidiana en Baztán a comienzos del siglo XX, ajustándose así al carácter social que animaba la convocatoria del certamen fotográfico. Ningún detalle, por insignificante que parezca, resulta gratuito; antes al contrario, todos ellos cumplen con su papel de configurar un panorama general, y adquieren su pleno significado en la visión final de conjunto, puestos unos al lado de otros, como si de las distintas piezas de un mismo puzzle se tratase.

Las labores se encuentran vinculadas a la agricultura y ganadería, y se desarrollan mayoritariamente junto al caserío, de manera que tan sólo excepcionalmente asistimos al trabajo del baserritarra en los prados cercanos (Antxoneazarrea de Lekaroz). En este caso además, el hombre faena en compañía del hijo mayor, lo cual constituye un valioso testimonio de la transmisión generacional de saberes.

Buena parte de las faenas del campo requiere de la ayuda de un sistema de tracción, ya sea para arar, arrastrar o transportar. Se usaba para ello una pareja de bueyes o vacas, siendo estas últimas más frecuentes en Baztán (Aldekoa y Antxoneazarrea de Lekaroz, Andalorrea de Gartzain). Menos habituales son las mulas o machos como animales de tiro (Iturbidea de Gartzain). Para el transporte se emplean carros de madera en sus diversas variantes, desde los más ligeros y de ruedas macizas como el carro "chillón", hasta aquellos de mayor tamaño y ruedas de radios; el cobertizo delantero de Aldekoa de Jauregizar de Irurita, y el doble espacio porticado de Arretxea de Oronoz, se convierten en inmejorables muestrarios de los diferentes tipos de carros. Otro aparejo era la lera, especie de trineo artesanal de madera tirado por vacas que se usaba para la recogida y transporte de la hierba y el helecho; su presencia en diversas fotografías (Iturbidea, Lapitzea e Irunberea de Gartzain, Aldekoa de Jauregizar de Irurita), deja bien a las claras su importancia en la economía rural baztanesa.

Aperos de labranza relacionados con el trabajo de la hierba son el arraztelu, rastrillo de mango largo con numerosos dientes de corta longitud que sirve para amontonarla (Aldekoa de Jauregizar de Irurita), la guadaña (de la que el baserritarra de Zaldarriaga de Elizondo porta únicamente el mango de madera), el sarde y la urtxila, variante del anterior con dos dientes, normalmente más largos (Lapitzea de Gartzain) ${ }^{78}$. Asimismo, la importancia que adquiere la elaboración o conservación de vino y sidra en la zona justifica la presencia de una enorme cuba próxima a la casa-palacio Arretexea de Oronoz. Junto a la agricultura, la cría de animales desempeña un papel básico en la economía doméstica baztanesa; en varias fotografías se hace presente el ganado de cerda, que servía tanto para el consumo propio del caserío como para su venta, ya fuera directa o de sus productos derivados. Por su parte, el bosque es un

\footnotetext{
77 Para el contexto socioeconómico del Valle de Baztán en el momento en que Fr. Pedro de Madrid realizó sus fotografías, consúltese Salinas Ramos (1992: 311-335). Y aunque el marco cronológico es algo anterior, resulta apropiado igualmente Arizcun Cela (1988).

78 Acerca de los aperos y herramientas de labranza característicos de un ámbito como el baztanés, resulta de utilidad la consulta de Caro Baroja (1969: 215-277).
} 
complemento importante, porque desde él se acarrea el helecho para cama del ganado y la leña y madera que sirven para satisfacer diversas necesidades: fuego para el hogar y para el horno de pan, piquetes para cierre de los campos, palos que sirven como guía de alubias (Aldekoa de Jauregizar de Irurita), y largas varas para varear los castaños (Arretxea de Oronoz).

La actividad productiva del caserío requería de toda la mano de obra disponible: hombres, mujeres y niños. En la organización del trabajo, cada uno tenía su función específica, si bien determinadas tareas requerían del concurso de todos. Las mujeres, además de las labores domésticas, colaboraban en las faenas del campo. En las imágenes de Fr. Pedro de Madrid, la mujer está muy presente, testimonio de la consabida idea del matriarcalismo del mundo rural vasco-navarro. La vemos aventando el trigo (Lapitzea de Gartzain), recogiendo la hierba (Iturbidea de Gartzain) y alimentando a los animales (Etxezuria de Amaiur). En Andalorrea de Gartzain, desciende por el patín acompañada de su hijo para coger agua del pozo que queda bajo el cobertizo, con la herrada sobre la cabeza apoyada en un rodete. En Beitiko Xaarrea de Lekaroz, las dos mujeres que asoman a sus balcones se convierten en testimonio de sendas tareas domésticas, el hilado y la colada. Todo ello sin olvidar que, en su papel de madre, quedaba a su cargo la crianza y educación de los hijos pequeños (Irunberea de Gartzain).

\section{CONCLUSIÓN}

A través de nuestro trabajo hemos pretendido una aproximación a la colección de caseríos del Valle de Baztán que bajo el lema Echezarra resultó triunfadora en el certamen fotográfico-social celebrado en Pamplona en 1912, así como a la figura de su autor, el fraile capuchino, músico, pintor y fotógrafo del Colegio de Lekaroz Fr. Pedro de Madrid, posteriormente establecido en Madrid y conocido como Pedro Satué y Foto Antsa. La colección constituye un magnífico ejemplo de las posibilidades que ofrece la fotografía como fuente documental, erigiéndose en una herramienta útil para abordar estudios etnográficos o antropológicos ${ }^{79}$. Su poder de síntesis y valor polisémico resultan incuestionables, pues como fuente primaria capta un instante irrepetible, definido por un espacio y tiempo concretos. El carácter dual de la colección —documento artístico a la par que etnográfico- la convierte en objeto museable; de ahí la presencia de algunas copias de la misma en el Museo San Telmo de San Sebastián, en la Fototeca de la Institución Príncipe de Viana, o en los fondos fotográficos de Eusko Ikaskuntza.

La imagen fotográfica nos ofrece un testimonio del pasado próximo de gran valor; pero como todas las fuentes, debe ser contextualizada, relacionada y complementada con otras fuentes. El lema Echezarra (Casa vieja) transmite la intención de su autor de reflejar una forma de vida basada en la institución social básica: el caserío. Su discurso visual idealiza la vida rural y las relaciones en torno a la vivienda y la familia, el paisaje y la heredad; en sus múltiples detalles, las fotografías del capuchino nos presentan la realidad de la vida cotidiana de Baztán hace un siglo. Para el análisis de un tipo de arquitectura rural, en parte ya desaparecida en cuanto a sus funciones y distribución de espacios pero que recupera protagonismo a comienzos

\footnotetext{
${ }^{79}$ Véase a este respecto Ortiz García, Sánchez-Carretero y Cea Gutiérrez (2005).
} 
del siglo XX de la mano del regionalismo, la colección es un documento de gran valor. Sin embargo, debemos recordar que Fr. Pedro de Madrid nos muestra una arquitectura y paisaje humanizados, ligados a quienes habitan el caserío y cultivan sus tierras, de tal manera que el caserío se erige en célula familiar y social, y en unidad de producción agraria basada en la heredad; de ahí la trascendencia que adquiere en el ámbito socioeconómico e ideológico en buena parte del territorio vasco-navarro.

En la actualidad se conservan la mayoría de los caseríos fotografiados por Fr. Pedro de Madrid en 1912, algunos de los cuales mantienen su función de vivienda, en tanto que otros se han convertido en bordas para el aprisco de ganado y almacenamiento de aperos. Tal continuidad física ofrece múltiples posibilidades, entre ellas la de la refotografía - técnica consistente en repetir una misma toma con un prolongado espacio de tiempo entre las dos imágenes-, que permite el análisis de las pervivencias y transformaciones producidas durante esta centuria; su aplicación, sugerencia con la que concluimos este artículo, se revelaría sin duda como un eficaz instrumento para el estudio, desde la sociología histórica o desde la etnografía, de determinados cambios significativos producidos en el transcurso del último siglo.

\section{BIBLIOGRAFÍA CITADA}

Alberdi Collantes, J. C. 2001. "Reestructuración agraria y abandono de usos: el caserío vasco". Investigaciones Geográficas 26: 135-150.

Alberdi Collantes, J. C. 2002. "El caserío agrícola vasco en proceso de desaparición”. Ería 57: 5-17.

Alberdi Collantes, J. C. 2009. "Medio rural y abandono de la agricultura. Desarrollo de un ejemplo: el caserío vasco". Lurralde. Investigación y espacio 32: 395-404.

Albisu Iriarte, A. 2006. Atondu, XXI. Menderako proposamena. Donostia: Elkar Argitaletxea.

Almandoz, K. 1997. "Metas: estudio etnográfico (belarrezko gorputza, egurrezko bihotza)". Cuadernos de Etnología y Etnografía de Navarra 70: 269-288.

Amesti Mendizábal, J. 1997. "El patín en los edificios civiles del Valle de Carranza”. Ondare. Cuadernos de Artes Plásticas y Monumentales 16: 55-106.

Aranzadi, E. 1932. La casa solar vasca o casa y tierras del apellido. Zarauz. Ed. Vasca.

Arizcun Cela, A. 1988. Economía y sociedad en un valle pirenaico del Antiguo Régimen. Baztán 16001841. Pamplona: Gobierno de Navarra.

Arozamena Ayala, A. 1998. "Manuel Torcida Torres", en Enciclopedia General Ilustrada del País Vasco, vol. XLVII. San Sebastián: Editorial Auñamendi. Estornés Lasa Hnos.

Atlas Etnográfico de Vasconia, 1-2, Casa y familia en Vasconia. 2011. Vitoria, Bilbao y Pamplona: Eusko Jaurlaritza, Etniker Euskalerria y Gobierno de Navarra.

Ávila Ojer, I. y López Echarte, M. C. 1996. "La casa en Navarra", en Etnografía de Navarra, no 3: 3348. Pamplona: Diario de Navarra.

Azanza López, J. J. 2012. La memoria de la memoria, 1212-1912. Tras las huellas artísticas del VII Centenario de las Navas de Tolosa. Pamplona: Gobierno de Navarra.

Azcona, T. de 2011. "La fotografía en el Colegio de Lecároz (Baztán)", en Fotografía en Navarra: fondos, colecciones y fotógrafos. Cuadernos de la Cátedra de Patrimonio y Arte Navarro 6. Pamplona: Cátedra de Patrimonio y Arte Navarro: 397-414.

Baeschlin, A. 1930. La arquitectura del caserío vasco. Barcelona: Editorial Canosa.

Benavent Oltra, J. A. 2008. "Del Museo Social de Barcelona al Institut psicotècnic de la Generalitat de Catalunya: origen, evolución y desaparición de una institución pionera y modélica de orientación psicopedagógica (1909-1939)". Revista Española de Orientación y Psicopedagogía 19, 1: 79-100.

Caro Baroja, J. 1969. "Un estudio de tecnología rural". Cuadernos de Etnología y Etnografía de Navarra 2: 215-277.

Caro Baroja, J. 1976. Baile, familia, trabajo. San Sebastián: Txertoa. 
Caro Baroja, J. 1982. La casa en Navarra, T. IV. Pamplona: Caja de Ahorros de Navarra.

Castro, C. 1916-18. Catálogo Monumental y Artístico de la Provincia de Navarra, T. I, Texto Manuscrito. En Catálogo_Digital CSIC, http://aleph.csic.es/imágenes/mad01/0010_CMTN/html/ 001359500_V01T.html\#page/1/mode/2up.

Clozier, R. 1936. Architecture eternel. París: Librairie de France.

Corral, J. 2002. La Gran Via: historia de una calle. Madrid: Sílex.

Cruz Mundet, J. R. 1997. "Caserío, familia y explotación agraria en Guipúzcoa: el ejemplo de Rentería (1750-1845)". Boletín de la Asociación de Demografía Histórica XV: 13-39.

Delgado Cendagortagalarza, A. 2008. La otra Bizkaia. Política en un medio rural durante la Restauración (1890-1923). Bilbao: Universidad del País Vasco.

Delgado Cendagortagalarza, A. 2009. Trabajo y vida cotidiana en la "otra" Bizkaia, 1876-1923. Madrid: Los Libros de la Catarata.

Díaz Morlán, P. 2002. Los Ybarra. Una dinastía de empresarios (1801-2001). Madrid: Marcial Pons.

Elorza Insausti, M. 2011. Espejo de un tiempo pasado. El País Vasco y la revista Novedades, 19091919/1928-1929. San Sebastián: Fundación Kutxa.

Enrique Guinea Maquibar, 1902-1944: fotografias 2010. Vitoria-Gasteiz: Ayuntamiento.

Etxezarreta, M. 1977. El caserío vasco. Bilbao: IKER.

Fernández Rius, N. 2011. Pau Audouard, fotògraf "retratista" de Barcelona. De la reputació a l'oblit (1856-1918). Barcelona: Universitat de Barcelona. En: http://www.tdx.cat/handle/10803/32063

Fusi Aizpurúa, J. P. 1975. Política obrera en el País Vasco (1880-1923). Madrid: Turner.

García Carretero, E. 2010. Celia Gámez. Memoria gráfica de la reina de la revista. Madrid: Ediciones Amberley.

García Gaínza, M. C., Orbe Sivatte, M., Domeño Martínez de Morentin, A. y Azanza López, J. J. 1994. Catálogo Monumental de Navarra. Merindad de Pamplona, T. V. Pamplona: Príncipe de Viana.

Goikoetxea López, I. 1991. "El caserío vasco: una unidad socioeconómica organizadora del territorio rural vasco-atlántico". Boletín de la Asociación de Geógrafos Españoles 13: 101-123.

Goñi Gaztambide, J. 1999. Historia de los obispos de Pamplona, T. XI. Siglo XX. Pamplona: EUNSA.

Grilli, D. 2006. "La fotografía de familia, una herramienta de construcción de la historia social", en Amador Carretero, M. P.; Robledano Arillo, J. y Ruiz Franco, M. R. (coords.), Cuartas Jornadas Imagen, Cultura y Tecnología: 233-248. Madrid: Editorial Archiviana y Universidad Carlos III.

Guimón, P. 1907. "El Caserío". Euzkadi 9: 33-64.

Guimón, P. 1919. "El caserío vasco”. Arquitectura 13: 120-124.

Guimón, P. 1924. "El alma vasca en su arquitectura", en La arquitectura moderna en Bilbao. Bilbao: Talleres Echeguren y Zulaica: 9-16.

Igoa Moreno, J. M. 2008. Arquitectura popular vasca: Baztán-Bidasoa. Irún: Luis de Iranzu Kultur Taldea.

Lago, S. 1915. "Bellas Artes. Exposición de Fotografías”. La Esfera, 10-7-1915.

Lasa, J. A. 2006. Estadística de la Provincia Capuchina de Navarra-Cantabria-Aragón: 1900-2006. Pamplona: Curia Provincial de Capuchinos.

Madariaga, N. 1980. El caserío como arquitectura popular vasca. Bilbao: Bizkaiko Aurrezki Kutxa.

Majuelo, E. y Pascual, A. 1991. Del catolicismo agrario al cooperativismo empresarial. Setenta y cinco años de la Federación de Cooperativas Navarras, 1910-1985. Madrid: Ministerio de Agricultura, Pesca y Alimentación.

Martín Galindo, J. L. 1969. El caserío vasco como tipo de explotación agraria. Valladolid: Universidad de Valladolid.

Martín López, A. M. y Muñoz García, M. 2004. Historia de la Real Sociedad Fotográfica. Segovia: Universidad SEK-Real Sociedad Fotográfica de Madrid.

Martinena Ruiz, J. J. 1977. Palacios cabo de armería (I). Col. Temas de Cultura Popular, no 283. Pamplona: Diputación Foral de Navarra.

Martinena Ruiz, J. J. 2008. Navarra. Castillos, torres y palacios. Pamplona: Príncipe de Viana.

Martínez, J. y Mauleón Gómez, J. R. 1994. "Sociedad rural tradicional y crisis del caserío en los años 1950-60", en Pensamiento agrario vasco. Mitos y realidades (1766-1980): 275-282. Bilbao: Instituto Vasco de Estudios Rurales.

Martínez Gorriarán, C. y Agirre Arriaga, I. 1995. Estética de la diferencia. El arte vasco y el problema de la identidad, 1882-1966. Irún: Alberdania. 
Mauleón, J. R. 1998. Estrategias familiares y cambios productivos del caserío vasco. Vitoria-Gasteiz: Gobierno Vasco.

Montijano Ruiz, J. J. 2013. Madrid frívolo. Breve historia de la revista musical madrileña y los teatros que la albergaron. Madrid: La Librería.

Muguruza, P. 1918. "Las construcciones civiles en el país vasco". Arquitectura 7: 199-202.

Muguruza, P. 1919. "La casa rural en el país vasco". Arquitectura 17: 244-248.

Navascués, P. 1993. Arquitectura Española, 1808-1914. Summa Artis. Historia General del Arte, vol. XXXV. Madrid: Espasa Calpe.

Olabarri Gortázar, I. 1978. Relaciones laborales en Vizcaya (1890-1936). Durango: Leopoldo Zuzaga Editor.

Ortiz García, C. 2005. "Fotos de familia. Los álbumes y las fotografías domésticas como hilo conductor de narrativas", en Ortiz García, C.; Sánchez-Carretero, C. y Cea Gutiérrez, A. (coords.), Maneras de mirar. Lecturas antropológicas de la fotografía: 189-210. Madrid: CSIC.

Ortiz García, C. 2006. "Una lectura antropológica de la fotografía familiar", en Amador Carretero, M. P.; Robledano Arillo, J. y Ruiz Franco, M. R. (coords.), Cuartas Jornadas Imagen, Cultura y Tecnología: 153-166. Madrid: Editorial Archiviana y Universidad Carlos III:.

Ortiz García, Carmen; Sánchez-Carretero, Cristina y Cea Gutiérrez, Antonio (coords.). 2005. Maneras de mirar. Lecturas antropológicas de la fotografía. Madrid: CSIC.

Pérez de Villarreal, V. 1988. "Armarria. Heráldica lapidaria baztanesa". Cuadernos de Etnología y Etnografía de Navarra 51: 179-233.

Posse y Villelga, J. 1916. "Lecciones sobre la vida social en el País Vasco", en Semana Social de España. Sexto curso: Pamplona, 29 de Junio a 6 de Julio 1912: 595-714. Pamplona: La Acción Social.

Posse y Villelga, J. 1920. "Los seguros sociales en el País Vasco. Forma como pudieran organizarse de modo que se desarrollen con garantías de permanencia y unidad de orientación", en II Congreso de Estudios Vascos: Pamplona 1920. Enseñanza y cuestiones económico-sociales: 380-399. San Sebastián: Eusko Ikaskuntza.

Rucabado, L. 1916. "Casa Don Dámaso Escoriaza. Bilbao". Arquitectura y construcción 282: 1-8.

Ruiz Urrestarazu, E. y Galdos Urrutia, R. 2005. "Reflexiones sobre la desestructuración del caserío vasco". Investigaciones Geográficas 38: 79-91.

Salinas Ramos, C. 1992. "Una aproximación a la evolución de la propiedad de la tierra en el valle de Baztán desde finales del siglo XIX hasta el primer tercio del XX". Príncipe de Viana, Anejo 16. II Congreso de Historia de Navarra de los siglos XVIII-XIX y XX: 311-335.

Sánchez Montalbán, F. J. 2006. "La fotografía de familia como objeto de investigación", en Amador Carretero, M. P.; Robledano Arillo, J. y Ruiz Franco, M. R. (coords.), Cuartas Jornadas Imagen, Cultura y Tecnología: 249-272. Madrid: Editorial Archiviana y Universidad Carlos III.

Sánchez Vigil, J. M. 1995. La documentación fotográfica en España. Revista La Esfera (1914-1920). Madrid: Universidad Complutense. En Eprints <http://eprints.ucm.es/tesis/19911996/S/3/S3005502.pdf>. Sánchez Vigil, J. M. 2003. La Esfera. Ilustración mundial (1914-1931). Madrid: Libris.

Santana, A. y Otero, X. 1993. Baserria: El caserío en Gipuzkoa. Donostia: Gipuzkoako Foro Aldundia. Semana Social de España. Sexto curso: Pamplona, 29 de Junio a 6 de Julio 1912. Pamplona: La Acción Social, 1916.

Sougez, M.-L. y Pérez Gallardo, H. 2009. Diccionario de historia de la fotografía. Madrid: Cátedra.

Urabayen, L. 1929. La casa en Navarra. Madrid: Espasa-Calpe.

Urabayen, L. 1984. "Esbozo de un programa destinado a fomentar la cultura popular y las enseñanzas especiales en el País Vasco", en III Congreso de Estudios Vascos: Guernica 1922. Lengua y enseñanza: 141-148. San Sebastián: Eusko Ikaskuntza.

Vigato, J. C. 1994. L'architecture régionaliste: France, 1890-1950. París: Norma.

Vitoria-Gasteiz. Historia gráfica 1993. Vitoria: Fundación Caja Vital Kutxa.

Yrízar, J. 1929. Las casas vascas. San Sebastián: Librería Internacional.

Zudaire Huarte, E. 1989. Lekaroz: Colegio "Nuestra Señora del Buen Consejo": (1888-1988). Burlada: Castuera.

Fecha de recepción: 21 de noviembre de 2012

Fecha de aceptación: 26 de agosto de 2013 